Article

\title{
In Vitro Anticancer Activity and Oxidative Stress Biomarkers Status Determined by Usnea barbata (L.) F.H. Wigg. Dry Extracts
}

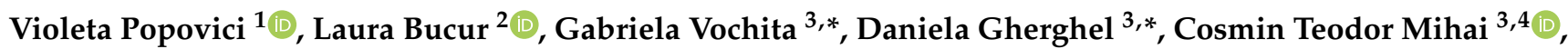 \\ Dan Rambu ${ }^{5}$, Suzana Ioana Calcan ${ }^{5}$, Teodor Costache ${ }^{5}$ D , Iulia Elena Cucolea ${ }^{5}$, Elena Matei ${ }^{6}$, \\ Florin Ciprian Badea ${ }^{7}$, Aureliana Caraiane ${ }^{7}$ and Victoria Badea ${ }^{1}$
}

Citation: Popovici, V.; Bucur, L.; Vochita, G.; Gherghel, D.; Mihai, C.T.; Rambu, D.; Calcan, S.I.; Costache, T.; Cucolea, I.E.; Matei, E.; et al. In Vitro Anticancer Activity and Oxidative Stress Biomarkers Status Determined by Usnea barbata (L.) F.H. Wigg. Dry Extracts. Antioxidants 2021, 10, 1141. https://doi.org/10.3390/ antiox10071141

Academic Editors: Neven Zarkovic and Suzana Borović Šunjić

Received: 29 June 2021

Accepted: 16 July 2021

Published: 20 July 2021

Publisher's Note: MDPI stays neutral with regard to jurisdictional claims in published maps and institutional affiliations.

Copyright: (c) 2021 by the authors. Licensee MDPI, Basel, Switzerland. This article is an open access article distributed under the terms and conditions of the Creative Commons Attribution (CC BY) license (https:/ / creativecommons.org/licenses/by/ $4.0 /)$.
1 Department of Microbiology and Immunology, Faculty of Dental Medicine, Ovidius University of Constanta, 7 Ilarie Voronca Street, 900684 Constanta, Romania; violeta.popovici@365.univ-ovidius.ro (V.P.); victoria.badea@365.univ-ovidius.ro (V.B.)

2 Department of Pharmacognosy, Faculty of Pharmacy, Ovidius University of Constanta, 6 Capitan Al. Serbanescu Street, 900001 Constanta, Romania; laurabucur@univ-ovidius.ro

3 NIRDBS, Institute of Biological Research Iasi, 47 Lascar Catargi Street, 700107 Iasi, Romania; mihai.cosmin.teo@gmail.com

4 Advanced Centre for Research and Development in Experimental Medicine (CEMEX), "Grigore T. Popa” University of Medicine and Pharmacy Iasi, 9-13 Mihail Kogalniceanu Street, 700259 Iasi, Romania

5 Research Center for Instrumental Analysis SCIENT, 1E Petre Ispirescu Street, 077167 Tancabesti, Ilfov, Romania; dan.rambu@scient.ro (D.R.); suzana.calcan@scient.ro (S.I.C.); teodor.costache@scient.ro (T.C.); iulia.cucolea@scient.ro (I.E.C.)

6 Center for Research and Development of the Morphological and Genetic Studies of Malignant Pathology, Ovidius University of Constanta, CEDMOG, 145 Tomis Blvd., 900591 Constanta, Romania; sogorescuelena@gmail.com

7 Department of Oral Rehabilitation, Faculty of Dental Medicine, Ovidius University of Constanta, 7 Ilarie Voronca Street, 900684 Constanta, Romania; florin.badea@365.univ-ovidius.ro (F.C.B.); aureliana.caraiane@365.univ-ovidius.ro (A.C.)

* Correspondence: gabriela.vochita@icbiasi.ro (G.V.); daniela.gherghel@icbiasi.ro (D.G.); Tel.: +407-4114-2032 (G.V.); +407-4823-5387 (D.G.)

Abstract: Lichens represent an important resource for common traditional medicines due to their numerous metabolites that can exert diverse pharmacological activities including anticancer effects. To find new anticancer compounds with fewer side effects and low tumor resistance, a bioprospective study of Usnea barbata (L.) F.H. Wigg. (U. barbata), a lichen from the Călimani Mountains (Suceava county, Romania) was performed. The aim of this research was to investigate the anticancer potential, morphologic changes, wound healing property, clonogenesis, and oxidative stress biomarker status of four extracts of $U$. barbata in different solvents (methanol, ethanol, acetone, and ethyl acetate), and also of usnic acid (UA) as a positive control on the CAL-27 (ATCC ${ }^{\circledR}$ CRL-2095 ${ }^{\mathrm{TM}}$ ) oral squamous carcinoma (OSCC) cell line and V79 $\left(\right.$ ATCC $^{\circledR}$ CCL-93 ${ }^{\mathrm{TM}}$ ) lung fibroblasts as normal cells. Using the MTT assay and according to $\mathrm{IC}_{50}$ values, it was found that the most potent anticancer property was displayed by acetone and ethyl acetate extracts. All $U$. barbata extracts determined morphological modifications (losing adhesion capacity, membrane shrinkage, formation of abnormal cellular wrinkles, and vacuolization) with higher intensity in tumor cells than in normal ones. The most intense anti-migration effect was established in the acetone extract treatment. The clonogenic assay showed that some $U$. barbata extracts decreased the ability of cancer cells to form colonies compared to untreated cells, suggesting a potential anti-tumorigenic property of the tested extracts. Therefore, all the $U$. barbata extracts manifest anticancer activity of different intensity, based, at least partially, on an imbalance in antioxidant defense mechanisms, causing oxidative stress.

Keywords: Usnea barbata dry extracts; usnic acid; CAL-27 cancer cells; V79 healthy cells; cytotoxicity; clonogenesis; wound healing assay; antioxidant enzymes activity 


\section{Introduction}

Nowadays, cancer still remains one of the most important causes of death, representing a challenge for the scientific community to search for new bioactive molecules that are effective and safe in the fight against this implacable disease of the contemporary world [1,2]. Particularly, OSCC represents more than $90 \%$ of all oral neoplasms, which have as common sites of development the tongue, lips, and floor of the mouth. This type of neoplasm has a high mortality rate (5-year survival rate of around $50 \%$ ) because numerous cases are diagnosed at a late stage of the disease [3]. The major purpose of current cancer therapy is to perturb or kill the malignant cells, from early stages neoplasms, or those remaining after surgery, without affecting the normal cytophysiological processes, and to trigger the immunity defense against the residual tumor cells. Most chemotherapeutic agents used in cancer treatment are toxic at effective doses, affecting the malignant cells and the normal ones from the body, require high dose therapy, have adverse side effects, develop multiple drug resistance (MDR) of cells, and are immunosuppressive. Therefore, finding new pharmacological agents with anticancer activity constitutes an essential concern of oncological research and medical practice to improve antitumor therapy effectiveness.

Natural products represent rich sources of bioactive molecules for new anticancer drugs $[4,5]$, and phytochemicals show great potential in improving the clinical condition in cancer patients, as demonstrated by numerous preclinical and clinical studies. Moreover, plant extracts and their secondary metabolites could promote cancer cell death by various molecular mechanisms [6-9]. Therefore, programmed tumor cell death (PCD) is one of the most known anticancer mechanisms and has three forms: apoptosis, necroptosis, and pyroptosis [10]. All of these PCDs vary directly proportional to ROS levels [11-13]. Apoptosis represents one of the most studied processes, consisting of non-inflammatory PGD. Numerous plant extracts and natural compounds induce apoptosis in neoplastic cells [14-16]. Furthermore, pyroptosis is an emerging inflammatory cell death mode, precepted as secondary necrosis after apoptosis; it is a lytic process that can be induced by the progressive loss of plasma membrane integrity of apoptotic cells $[17,18]$. Both PCD processes are caspase-dependent molecular mechanisms [19]; in addition, Jiang et al. (2020) highlighted that the caspase-3/GSDME signal pathway is a switch between apoptosis and pyroptosis in cancer [17]. Finally, necroptosis is an alternative mode of pro-inflammatory PCD, surnamed programmed necrosis, overcoming apoptosis. It also reportedly serves as a "fail-safe" mechanism that protects against tumor development when resistance processes compromise apoptosis [20,21]. With ferroptosis and parthanatos, necroptosis represents a caspase-independent regulated necrosis pathway [22]. Necroptosis and pyroptosis trigger pro-inflammatory signals into the cellular surroundings; contrariwise, apoptosis dampens subsequent immune responses [10] (p. 1106). Several scientific studies have reported that natural products could induce pro-inflammatory programmed tumor cell death. For instance, Oregano vulgare L., [23], Acridocarpus orientale [24], and Galenia africana [25] registered antitumor effects by apoptosis and necroptosis. Pujari et al. (2021) proved that moscatylin (a plant-derived stilbenoid compound) displays anticancer effects by apoptosis and pyroptosis [26]. Another study proved that ferroptosis, apoptosis, and autophagy are antitumor mechanisms of Thymus vulgaris and Arctium lappa on leukemia and multiple myeloma tumor cell lines [27].

In the last years, novel cancer treatment strategies exploiting pro-senescence therapies have attracted remarkable interest [28,29]. Cellular senescence represents a state of stable cell cycle arrest that could be promoted as a response to various injuries; this state consists of indistinct morphological hallmarks, gene expression profiles, and the senescence-associated secretory phenotype (SASP) [30]. Cellular senescence is an important component of normal physiology with tumor-suppressive functions [31]. As a natural compound, hinokitiol (natural monoterpenoid) induces DNA damage and autophagy, followed by cell cycle arrest and senescence in gefitinib-resistant lung adenocarcinoma cells, as reported Li et al. (2014) [32]. In another study, Zheng et al. (2017) proved that an optimized plant mixed 
formula had anticancer action inducing cell cycle arrest and senescence against lung tumor cells [33].

However, cell cycle arrest cannot mean only senescence [34]. The cell cycle can be stopped in various phases (G0/G1; G1/G2; G2/M) and cell proliferation could be inhibited. Thus, Nguyen et al. (2017) communicated that quercetin promotes tumor cell apoptosis and cell cycle arrest in G2/M [35]. In other studies, Litsea cubeba (Lour.) heartwood and fruit extracts showed a cytotoxic effect against T47D breast cancer cells, arresting the cell cycle in G0/G1 [36]; likewise, De Souza Grinevicius et al. (2016) described Piper nigrum ethanolic extract anticancer activity, which causes high ROS production, oxidative damage in DNA inducing cell cycle arrest, and apoptosis in cancer cells [37].

A large part of biomolecules derived from plants can act synergistically with chemoand radiotherapy. This association could increase the therapeutic effects and could reduce the side effects due to lower doses of conventional therapeutics needed [38-43]. Lichens are part of a particular group of symbiotic organisms, representing the association between a fungus and a green alga or a cyanobacterium, producing numerous secondary metabolites [44,45]. Lichens have been used in traditional medicine from ancient times [46]. It has been observed that many lichens have an unpleasant taste and can serve as a defense against herbivores. The secondary metabolites manifest significant biological and pharmacological properties such as antibacterial, antiviral, anti-inflammatory, antipyretic, anti-proliferative, and cytotoxic effects [47-49]. Moreover, these compounds have revealed antineoplastic activities in preclinical studies [50-54]. One of the secondary metabolites of lichens is usnic acid $\left(\mathrm{C}_{18} \mathrm{H}_{16} \mathrm{O}_{7}\right)$ [2,6-diacetyl-7,9-dihydroxy-8,9b-dimethyldibenzofuran$1,3(2 \mathrm{H}, 9 \mathrm{bH})$-dione)], predominantly found in the Alectoria, Cladonia, Evernia, Lecanora, Ramalina, and Usnea genera, constituting about $4-8 \%$ of the dry weight of thalli, which depends on the environmental conditions [55]. It has been shown that UA manifests antiviral, antimicrobial, antiprotozoal, anti-inflammatory, anti-metastatic, anti-angiogenic, anti-proliferative, wound-healing, and analgesic activity, making this compound an interesting subject for the pharmaceutical industry [56-59].

Therefore, our research aimed to investigate the anticancer potential of some extracts of Usnea barbata (L.) F.H. Wigg (named Song Luo in China, commonly called Old Man's Beard), a lichen used for over 2000 years in Chinese traditional medicine [60]; this lichen was collected from the Călimani Mountains, Romania. Four dry extracts of Usnea barbata (L.), using various solvents, were obtained, in which the usnic acid, polyphenols, and tannins were previously quantified [61]. The in vitro antitumor property of these four dry extracts on the CAL-27 cancer cell line (tongue) was highlighted by assessing their cytotoxic activity, morphological changes, wound healing capacity, clonogenesis, and antioxidant enzyme system activity. Likewise, an evaluation of in vitro toxicity of the studied extracts was realized on non-cancerous V79 cells (lung fibroblasts). This study emphasizes the usefulness of the lichens in cancer treatment and their pharmacological potential, making them good candidates for new drug discovery.

\section{Materials and Methods}

\subsection{Preparation and Characterization of Lichen Extracts}

Four $U$. barbata extracts were studied using different solvents: methanol extract (UBM), ethanol extract (UBE), acetone extract (UBA), and ethyl acetate extract (UBEA). Additionally, as a positive control, UA was tested and obtained according to the protocol presented in our previous work [61] (p. 919). U. barbata was harvested from Calimani Mountains forests, Suceava County, Romania. The fresh lichen was cleaned of impurities and dried at $18-25^{\circ} \mathrm{C}$ and sheltered from the sun in a herbal room. After drying, the obtained herbal product was preserved for a long time in the same conditions for subsequent studies. The lichen species identification was performed by the Department of Pharmaceutical Botany of the Faculty of Pharmacy, Ovidius University of Constanta, using standard methods. The dried lichen was ground to a powder; $60 \mathrm{~g}$ dried were extracted in a Soxhlet continuous reflux system, for eight hours with $450 \mathrm{~mL}$ of each solvent: acetone, ethanol (Chimreactiv 
S.R.L., Bucharest, Romania), ethyl acetate, methanol (Chemical Company, Iasi, Romania), The extraction process was different for each extract, being around the boiling point of each solvent (Table 1). The rotary evaporator TURBOVAP 500 Caliper (Hopkinton, MA, USA) was used for evaporation of the solvents. Next, these extracts were kept for $16 \mathrm{~h}$ in a chemical exhaust hood for each optimal solvent evaporation. The obtained dry extracts were transferred to sealed-glass bottles and stored in the freezer (Sirge ${ }^{\circledR}$, Avigliana (TO) Italia) at $-24{ }^{\circ} \mathrm{C}$ until processing [61] (p. 919) (Supplementary Materials Figure S1).

The IR spectra of the four $U$. barbata dry extracts were obtained using the Frontier FTIR spectrometer produced by PerkinElmer ${ }^{\circledR}$ (Waltham, MA, USA) equipped with the ATR (attenuated total reflectance) accessory in the range $4000-400 \mathrm{~cm}^{-1}$ at a resolution of $4 \mathrm{~cm}^{-1}$. Several $\mathrm{mg}$ of each sample was placed on the ATR crystal surface, and the obtained spectrum was the average of 16 readings. Each sample was analyzed in duplicate. The obtained results (with Spectrum ${ }^{\mathrm{TM}} 10$ software from PerkinElmer $^{\circledR}$, Waltham, MA, USA) were interpreted based on the table with IR spectra according to the frequency range provided online by the Sigma Library of FTIR Spectra, Volumes 1 and 2 [62-64] and compared to those found in the literature.

\subsection{Cell Lines and Cell Culture}

The tumor and normal cell lines, respectively human OSCC cells CAL-27 (ATCC ${ }^{\circledR}$ CRL$2095^{\mathrm{TM}}$ ) and normal lung fibroblasts from Chinese hamster V79 (ATCC ${ }^{\circledR}$ CCL-93 ${ }^{\mathrm{TM}}$ ), were obtained from American Type Culture Collection (ATCC, Rockville, MD, USA). Both cell lines were cultured in Dulbecco's modified Eagle's medium (DMEM, Biochrom AG, Berlin, Germany) with fetal bovine serum (FBS, Thermo Fisher Scientific, Berlin, Germany), 10\%), antibiotic solution (Biochrom AG, Berlin, Germany) containing penicillin (100 IU/mL), and streptomycin $(100 \mu \mathrm{g} / \mathrm{mL})$, in a Binder incubator (BINDER GmbH, Tuttlingen, Germany) at $37^{\circ} \mathrm{C}$ and $5 \% \mathrm{CO}_{2}$ to guarantee growth and viability.

\subsection{MTT Assay}

MTT assay is a colorimetric method, modified after Mosmann (1983) [65] and Laville et al. (2004) [66], which is an exact and sensitive method suitable for adherent cell cultures, based on the capacity of NAD $(\mathrm{P}) \mathrm{H}$-dependent cellular oxidoreductase to convert yellow soluble tetrazolium [3-(4, 5-dimethyl thiazolyl-2)- 2,5-diphenyltetrazolium bromide] (MTT) into insoluble (E, Z)-5-(4,5-dimethylthiazol-2-yl)-1,3-diphenyl formazan (formazan) [67], subsequently dissolved with DMSO, resulting in a purple color whose intensity is directly proportional to the number of living cells [68], with the absorbance being converted in a number of cells based on standard curves realized with known cell dilutions [69]. The absorbance was measured at $570 \mathrm{~nm}$ with a Biochrom EZ Read 400 automatic microplate reader (Biochrom AG, Berlin, Germany). The cellular viability expressed as a percentage was calculated with the formula:

$$
\text { Cell viability }(\%)=(\text { Abs. }) \text { Test } /(\text { Abs. }) \text { Control } \times 100 \text {, }
$$

where Abs is the absorbance.

The $U$. barbata extracts were dissolved in DMSO $0.2 \%$, then diluted with culture medium to realize different concentrations (from 25 to $200 \mu \mathrm{g} / \mathrm{mL}$ ); usnic acid was also dissolved in DMSO $0.2 \%$ and diluted to obtain a range of doses from 1.25 to $10 \mu \mathrm{g} / \mathrm{mL}$ and used as a positive control. The untreated cells with the same volume of culture medium were the control group. The adherent cells were seeded in 96 -well plates $\left(6 \times 10^{3}\right.$ cells $/$ well for V79 cells and $9 \times 10^{3}$ cells/well for CAL-27 cells). After incubation for $24 \mathrm{~h}$ (monolayer formation), cells were treated 24 and $48 \mathrm{~h}$ with 25, 50, 100, and $200 \mu \mathrm{g} / \mathrm{mL} U$. barbata extracts and $1.25,2.5,5$, and $10 \mu \mathrm{g} / \mathrm{mL}$ usnic acid. Subsequently, the culture medium was replaced with $100 \mu \mathrm{L}$ fresh medium, and $10 \mu \mathrm{L}$ MTT $(5 \mathrm{mg} / \mathrm{mL})$ solution was added to each well and incubated for $3 \mathrm{~h}$. Then, $90 \mu \mathrm{L}$ of the mixture was removed, and $50 \mu \mathrm{L}$ of DMSO was added into each well to dissolve the formazan crystals, the absorbance being measured with a microplate reader. The $\mathrm{IC}_{50}$ values were calculated from the concentrations of the 
$U$. barbata extracts that induced 50\% inhibition of cell growth. Each test was repeated three times independently.

\subsection{Cell Morphology Assay}

The CAL-27 and V79 cells morphology was observed by the Nikon Eclipse TS 100 inverted microscope (Nikon, Tokyo, Japan) equipped with MshOt MS60 (Nikon, Tokyo, Japan) digital microscope camera after 24 and $48 \mathrm{~h}$ treatment of the $U$. barbata extracts. The images were saved as JPEGs.

\subsection{In Vitro Wound Healing Assay}

The cell migration was estimated by the in vitro scratch method [70,71]. The cells were seeded in 24 well plates, $3 \times 10^{4}$ cells/well for V79 cells and $5 \times 10^{4}$ cells/well for CAL 27 cells. After $24 \mathrm{~h}$ of monolayer formation, the scratch was made using a sterile $200 \mu \mathrm{L}$ pipette tip, and the cells were washed twice with ice-cold phosphate-buffered saline (PBS) with $\mathrm{pH} 7.4$ to remove the cell debris. Afterward, the cells were treated for $24 \mathrm{~h}$ with the concentration values of $\mathrm{IC}_{50}$ of the four $U$. barbata extracts and usnic acid established from the MTT assay for $48 \mathrm{~h}$. The cells without treatment were used as the negative control and $0.2 \%$ DMSO as the vehicle control. The first set of images showing the edge of the scratch was observed immediately after incubation at $0 \mathrm{~h}$ (T0) with an inverted microscope (Nikon Eclipse TS 100, Tokyo, Japan) and 10× objective. The micro-images were taken using a MS60-2-6.3MP sCMOS camera (Nikon, Tokyo, Japan). The next set of images were taken at different time intervals $(24 \mathrm{~h}$ and $48 \mathrm{~h}$ for both the cell line and supplementary, at $96 \mathrm{~h}$ in CAL-27 cells) until the complete wound closure of the control. In order to determine the migration rate, the images were analyzed using ImageJ software, and the percentage of the closed area was measured compared to the value obtained at $\mathrm{T} 0 \mathrm{for}$ each variant. The experiment was performed in triplicate.

\subsection{Clonogenic Assay}

According to Franken et al. (2007) [72] and Rafehi et al. (2011) [73], the clonogenic assay was applied to appreciate cell survival. Briefly, CAL-27 cancer cells and V79 normal cells were seeded in 12-well plates (100 cells/well) and allowed to grow for two days. After culture initiation, the $48 \mathrm{~h}$ treatment was applied with the specific $\mathrm{IC}_{50}$ values previously established for the $U$. barbata extracts and the usnic acid and $0.2 \%$ DMSO. When the treatment time expired, the growth medium was discarded and replaced with fresh complete DMEM. Until the colonies reached a minimum of 50 cells/colony (14 days), the growth medium was replaced every two days. After colonies from the control group were formed (over 50 cells/colony), the colonies were washed with PBS, fixed with ethanol, and stained with Trypan blue. Colonies were counted and analyzed with FIJI software [74]. Three independent determinations were performed.

\subsection{Antioxidant Enzymes Activity Assay}

To estimate the effect of $U$. barbata extracts on some biomarkers of oxidative stress, the activity of the main antioxidant enzymes, superoxide dismutase (SOD), catalase (CAT), and glutathione peroxidase (GPX) as well as the level of malondialdehyde (MDA), a product resulting from the lipid peroxidation, were evaluated. For these determinations, the cells were grown in DMEM, to which $10 \%$ fetal bovine serum and $1 \%$ penicillin-streptomycin were added, at $37^{\circ} \mathrm{C}$ in a humidified atmosphere with $5 \% \mathrm{CO}_{2}$ binder incubator. After obtaining the cell monolayer, the cells were treated for $6 \mathrm{~h}$ with $\mathrm{IC}_{50}$ specific values of each $U$. barbata extract. A positive control was performed, meaning $100 \mu \mathrm{M} \mathrm{H}_{2} \mathrm{O}_{2}$ treatment for $15 \mathrm{~min}$, twice washed with cold phosphate-buffered saline (PBS) solution, and then trypsinized simultaneously with other treated groups to obtain the cell lysates. The samples were ultrasonicated in ice-cold $0.1 \mathrm{M}$ potassium phosphate buffer $(\mathrm{pH} 7.4), 1.15 \% \mathrm{KCl}$, at a $8 \times 10$ cycle, power $35 \%$, for $1 \mathrm{~min}$, repeated 8 times, then centrifuged ( $15 \mathrm{~min}$ at $3000 \mathrm{rpm}$ ), and the supernatant was used in determinations for biomarkers of oxidative stress [75,76]. 


\subsubsection{Determination of Superoxide Dismutase Activity}

Superoxide dismutase (SOD) activity was determined according to Winterbourne's method with slight changes, based on the SOD ability to inhibit the reduction of nitro blue tetrazolium (NBT) by superoxide radicals resulting through the reoxidation of photochemically reduced riboflavin. The degree of inhibition determined by the enzyme was estimated by measuring the treated samples and controlling extinctions at $562 \mathrm{~nm}$ against distilled water [77].

\subsubsection{Determination of Catalase Activity}

Sinha's assay evaluates catalase (CAT) activity with minor adaptations [78]. CAT acts on hydrogen peroxide for a well-defined period, after which it is inactivated by adding a mixture of potassium dichromate-acetic acid. After CAT inactivation, the amount of unmodified oxygenated water was reduced in the acid medium, the potassium dichromate, to chromic acetate, which was determined at $570 \mathrm{~nm}$. The difference between the initial and final quantity of oxygenated water in the reaction medium constitutes the amount of oxygenated water decomposed by catalase.

\subsubsection{Determination of Glutathione Peroxidase Activity}

Glutathione peroxidase (GPx) activity was assessed using the protocol described by Fukuzawa and Tokumura [79]. GPx catalyzes the decomposition of hydrogen peroxide $\left(\mathrm{H}_{2} \mathrm{O}_{2}\right)$ with the participation of reduced glutathione as a reducer, resulting in oxidized glutathione (G-S-S-G) and water. The remaining reduced glutathione reacts with DTNB to form a yellow complex. The intensity is measured spectrophotometrically, with the difference between the initial and final amount being directly proportional to the enzymatic activity [80].

\subsubsection{Determination of Malondialdehyde Levels}

Malondialdehyde (MDA) was determined by the modified method of Ohkawa et al. (1979) [76]. The principle of the method consists of the reaction of MDA, resulting from the decomposition of lipid peroxides at high temperature and in acidic medium with 2-thiobarbituric acid (TBA), forming a pink trimetine adduct MDA-TBA2, with maximum absorption at $532 \mathrm{~nm}$.

The activity for each enzyme was expressed as enzyme units per mg of protein. Determination of protein concentration was realized from the same cellular lysate by the Bradford assay. The principle of the method is based on the observation that the maximum absorption for the acidic solution of Coomassie Brilliant Blue G-250 changes from $465 \mathrm{~nm}$ to $595 \mathrm{~nm}$ when protein binding occurs [81].

\subsection{Statistical Analysis}

The results of the in vitro trial were expressed as the average of three parallel tests \pm standard error (ES). The difference between the mean values for each parameter was expressed by the Student's $t$-test, using software GraphPad Prism version 8 (San Diego, CA, USA) [82].

\section{Results}

\subsection{Preparation and Characterization of Lichen Extracts}

All the data are shown in Table 1 and Supplementary Materials Figure S1. The secondary metabolite content was determined in our previous study, and the obtained results are also synthesized in Table 1 (where $\mathrm{DE}=$ dry extract). 
Table 1. Preparation and characterization of the four $U$. barbata dry extracts.

\begin{tabular}{ccccccc}
\hline U. barbata Dry Extract & Color & Temperature & Yield\% & $\begin{array}{c}\text { UA } \\
\text { (mg/g) }\end{array}$ & $\begin{array}{c}\text { TPC } \\
(\mathbf{m g} / \mathbf{g} \text { DE) }\end{array}$ & $\begin{array}{c}\text { TC } \\
(\mathbf{m g} / \mathbf{g} \text { DE) }\end{array}$ \\
\hline UBE & Light-brown & $75-80^{\circ} \mathrm{C}$ & 12.52 & 127.21 & 67.3 & 14.7 \\
\hline UBM & Brown & $65^{\circ} \mathrm{C}$ & 11.29 & 137.60 & 70.7 & 9.99 \\
\hline UBA & Yellow-brown & $55-60^{\circ} \mathrm{C}$ & 6.36 & 282.78 & 101.09 & 24.4 \\
\hline UBEA & Brown-yellow & $75-80^{\circ} \mathrm{C}$ & 6.27 & 376.73 & 42.40 & 3.85 \\
\hline
\end{tabular}

The spectra acquisition for each of the four U. barbata dry extracts (Figure 1a-d) on the range $4000-400 \mathrm{~cm}^{-1}$ were analyzed individually to identify the main functional groups and superimposed to assess the similarity degree (Figure 1e).

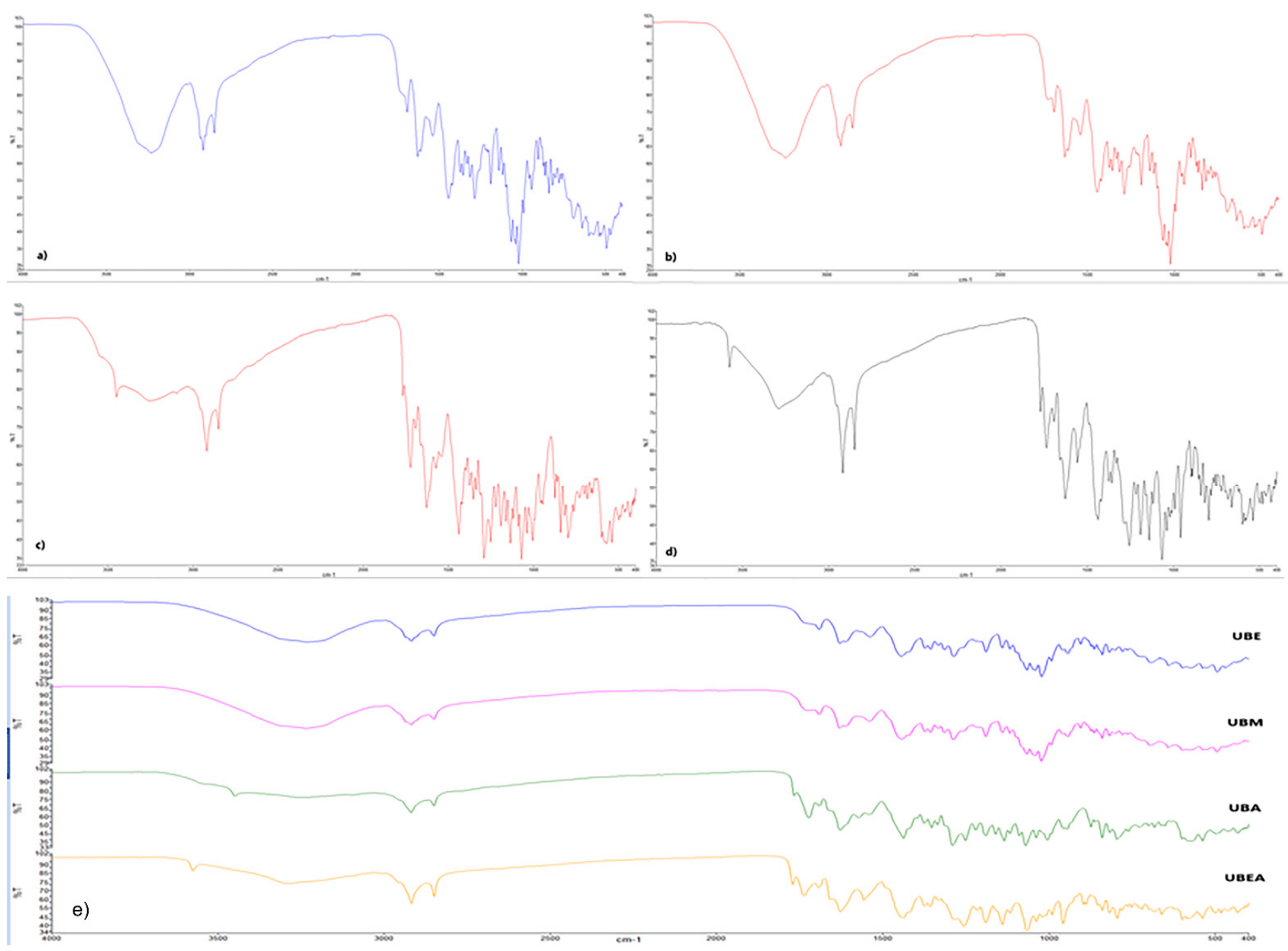

Figure 1. FTIR spectra of $U$. barbata extracts. (a) in ethanol (UBE); (b) in methanol (UBM); (c) in acetone (UBA); (d) in ethyl acetate (UBEA); (e) Overlapping FTIR-ATR spectra of all extracts: Blue-extract in ethanol, Purple-extract in methanol, Green-extract in acetone, Orange-extract in ethyl acetate.

The detailed FTIR spectra with recorded peaks of each extract and usnic acid are included in the Supplementary Materials (Figures S2-S7). The prominent peaks in the region $4000-1500 \mathrm{~cm}^{-1}$ (region of functional groups) were examined; their frequency and interpretation are synthesized in Table 2. 
Table 2. IR spectrum analysis of the four extracts in the range of $4000-1500 \mathrm{~cm}^{-1}$.

\begin{tabular}{|c|c|c|c|c|c|c|c|c|}
\hline \multirow{2}{*}{$\begin{array}{c}\text { U. barbata Extract } \\
\text { Domain }\left(\mathrm{cm}^{-1}\right)\end{array}$} & \multicolumn{2}{|r|}{ UBA } & \multicolumn{2}{|c|}{ UBE } & \multicolumn{2}{|c|}{ UBM } & \multicolumn{2}{|c|}{ UBEA } \\
\hline & Frequency & Interpretation & Frequency & Interpretation & Frequency & Interpretation & Frequency & Interpretation \\
\hline \multirow{4}{*}{$\begin{array}{c}4000-2500 \mathrm{~cm}^{-1} \\
\text { single bonds } \\
\text { region }\end{array}$} & $\begin{array}{c}3448 \\
\text { (sharp) }\end{array}$ & $\begin{array}{l}\mathrm{N}-\mathrm{H} \text { secondary amine } \\
\text { in aromatic nucleus }\end{array}$ & NA & & NA & & $\begin{array}{c}3575 \\
\text { (sharp) }\end{array}$ & $\mathrm{OH}$ (phenol) \\
\hline & $\begin{array}{c}3242 \\
\text { (broad) }\end{array}$ & $\begin{array}{c}\mathrm{OH} \\
\text { (phenol) }\end{array}$ & $\begin{array}{c}3230 \\
\text { (broad) }\end{array}$ & $\begin{array}{c}\mathrm{OH} \\
\text { (phenol) }\end{array}$ & $\begin{array}{c}3235 \\
\text { (broad) }\end{array}$ & $\begin{array}{c}\mathrm{OH} \\
\text { (phenol) }\end{array}$ & $\begin{array}{c}3289 \\
\text { (broad) }\end{array}$ & $\begin{array}{c}\mathrm{OH} \\
\text { (phenol) }\end{array}$ \\
\hline & 2918 & $\begin{array}{l}\text { C-H (alkane) } \\
\text { stretching }\end{array}$ & 2918 & $\begin{array}{l}\text { C-H (alkane) } \\
\text { stretching }\end{array}$ & 2918 & $\begin{array}{l}\text { C-H (alkane) } \\
\text { stretching }\end{array}$ & 2918 & $\begin{array}{l}\text { C-H (alkane) } \\
\text { stretching }\end{array}$ \\
\hline & 2850 & $\begin{array}{c}\mathrm{C}-\mathrm{H} \\
\text { stretching }\end{array}$ & 2850 & $\begin{array}{c}\mathrm{C}-\mathrm{H} \\
\text { stretching }\end{array}$ & 2851 & $\begin{array}{c}\mathrm{C}-\mathrm{H} \\
\text { stretching }\end{array}$ & 2849 & $\begin{array}{c}\mathrm{C}-\mathrm{H} \\
\text { stretching }\end{array}$ \\
\hline $\begin{array}{c}2500-2000 \mathrm{~cm}^{-1} \\
\text { triple bonds } \\
\text { region }\end{array}$ & NA & & NA & & NA & & NA & \\
\hline \multirow{6}{*}{$\begin{array}{c}2000-1500 \mathrm{~cm}^{-1} \\
\text { double bonds } \\
\text { region }\end{array}$} & 1767 & $\begin{array}{l}\mathrm{C}=\mathrm{O} \\
\text { stretching }\end{array}$ & NA & & NA & & 1771 & $\begin{array}{c}\mathrm{C}=\mathrm{O} \\
\text { stretching }\end{array}$ \\
\hline & 1721 & $\begin{array}{c}\mathrm{C}=\mathrm{O} \\
\text { (carboxylic acid) }\end{array}$ & NA & & NA & & 1736 & ( $\delta$-lactone) \\
\hline & 1691 & $\mathrm{C}=\mathrm{O}$ & 1691 & $\mathrm{C}=\mathrm{O}$ & 1692 & $\mathrm{C}=\mathrm{O}$ & 1693 & $\mathrm{C}=\mathrm{O}$ \\
\hline & 1627 & $\begin{array}{l}\text { Aromatic compound } \\
\qquad \mathrm{C}=\mathrm{C}\end{array}$ & 1629 & $\begin{array}{l}\text { Aromatic } \\
\text { compound } \\
\mathrm{C}=\mathrm{C}\end{array}$ & 1629 & $\begin{array}{l}\text { Aromatic } \\
\text { compound } \\
\mathrm{C}=\mathrm{C}\end{array}$ & 1628 & $\begin{array}{l}\text { Aromatic } \\
\text { compound } \\
\mathrm{C}=\mathrm{C}\end{array}$ \\
\hline & 1572 & $\mathrm{C}=\mathrm{O}$ (amides) & NA & & NA & & NA & \\
\hline & 1542 & Carboxylic OH & 1537 & Carboxylic $\mathrm{OH}$ & 1541 & Carboxylic $\mathrm{OH}$ & 1557 & Carboxylic $\mathrm{OH}$ \\
\hline
\end{tabular}




\subsection{MTT Assay}

In vitro screening on normal and tumor mammalian cell cultures aimed to investigate the effect of four $U$. barbata extracts on the viability of human squamous carcinoma cells CAL-27 and normal lung fibroblasts from Chinese hamster V79 using the MTT viability assay. The two cell lines were incubated with the four extracts for 24 and $48 \mathrm{~h}$, with doses ranging from 25 to $200 \mu \mathrm{g} / \mathrm{mL}$. Usnic acid was used as a positive control in the dose range of $1.25-10 \mu \mathrm{g} / \mathrm{mL}$. The cytotoxic effect of $U$. barbata extracts on cancer CAL-27 cells is illustrated in Figures 2 and 3. Thus, the methanol extract of $U$. barbata (UBA) interferes slightly with CAL-27 cell viability after $24 \mathrm{~h}$ treatment at the lower used dose $(25 \mu \mathrm{g} / \mathrm{mL})$, with a value of $77.15 \%$, which decreased to $58.59 \%$ after $48 \mathrm{~h}$ of treatment. At the maximum used dose $(200 \mu \mathrm{g} / \mathrm{mL})$, there was a slightly more pronounced decrease in cell viability after $24 \mathrm{~h}$ of treatment (54.45\%) and $48 \mathrm{~h}$ of treatment to decrease to $41.06 \%$. The ethanol extract of $U$. barbata (UBE) behaved similarly to the methanol extract, determined at $25 \mu \mathrm{g} / \mathrm{mL}$ viability of $76.36 \%$ after $24 \mathrm{~h}$ treatment and $66.373 \%$ after $48 \mathrm{~h}$ treatment.

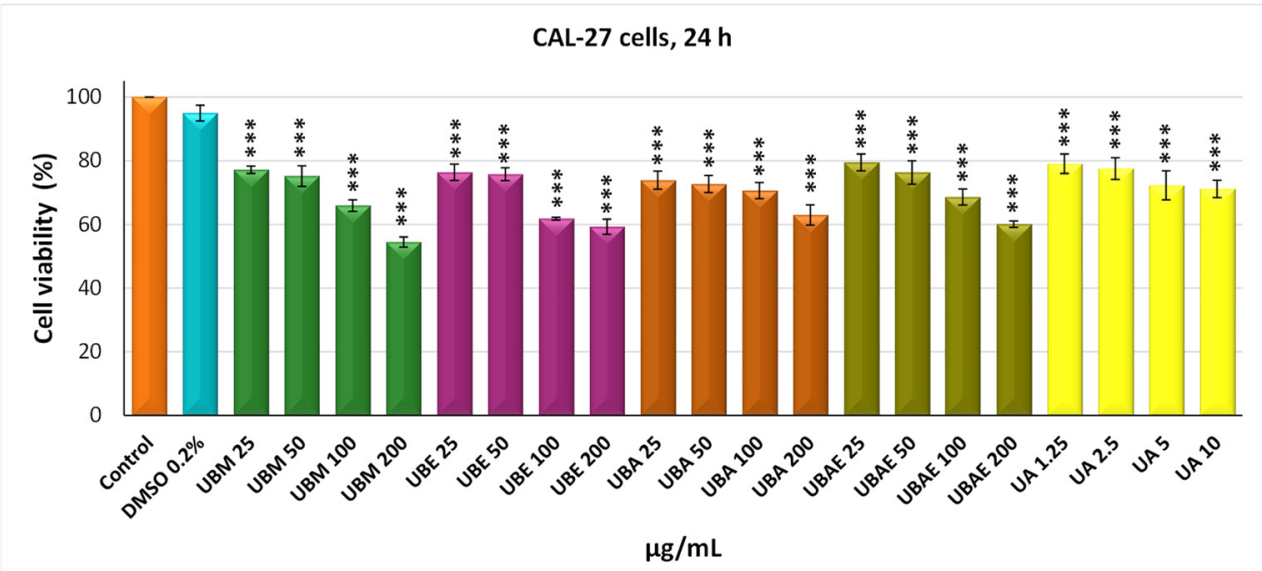

Figure 2. The viability of the CAL-27 cells after $U$. barbata extracts $(\mu \mathrm{g} / \mathrm{mL})$ treatment $(24 \mathrm{~h})$. The results represent the mean $\pm \mathrm{SE}$ of three independent experiments $(* * *<0.001)$ when comparing the untreated control ( $t$-test).

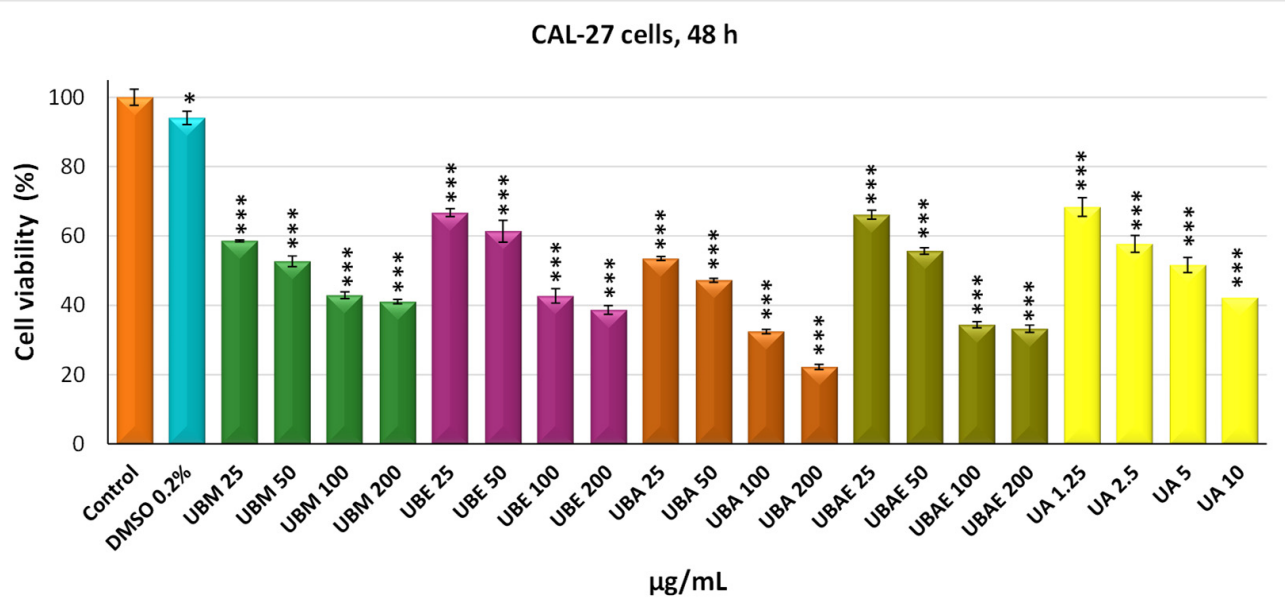

Figure 3. The viability of the CAL-27 cells after treatment of the $U$. barbata extracts $(\mu \mathrm{g} / \mathrm{mL})(48 \mathrm{~h})$. The results represent the mean $\pm \mathrm{SE}$ of three independent experiments $\left({ }^{*} p<0.05,{ }^{* * *} p<0.001\right)$ when comparing the untreated control ( $t$-test).

There was a decrease in cell viability with the dose, at $200 \mu \mathrm{g} / \mathrm{mL}$ being recorded a value of $59.25 \%$ at $24 \mathrm{~h}$ and of $38.67 \%$ at $48 \mathrm{~h}$. The impact of the acetone extract of $U$. barbata (UBA) upon cancer cell viability was moderate at $25 \mu \mathrm{g} / \mathrm{mL}$, determining values 
of $73.88 \%$ at $24 \mathrm{~h}$ treatment and of $53.49 \%$ at $48 \mathrm{~h}$. The situation changed significantly, especially at the dose of $200 \mu \mathrm{g} / \mathrm{mL}$ and after $48 \mathrm{~h}$ of treatment, when a pronounced decrease in cell viability was reported of $22.25 \%$. The ethyl acetate extract of $U$. barbata (UBEA) determined insignificant decreases in cell viability at $24 \mathrm{~h}$ of $79.47 \%(25 \mu \mathrm{g} / \mathrm{mL})$ and $60.08 \%(200 \mu \mathrm{g} / \mathrm{mL})$. The 48 -h treatment with UBEA was followed by decreases in the viability of neoplastic cells, which were not so pronounced at $25 \mu \mathrm{g} / \mathrm{mL}(66.15 \%)$, but significantly reduced at $200 \mu \mathrm{g} / \mathrm{mL}$, reaching values of $33.25 \%$ (Figure 3 ).

In addition, the in vitro trial included testing the $U$. barbata extracts on a healthy cell line, normal lung fibroblasts from Chinese hamster, V79 (Figures 4 and 5). On this cell line, it was observed that the cytotoxic effect of the four $U$. barbata extracts was generally lower compared to that manifested on the CAL-27 tumor line. Thereby, the UBM extract at $24 \mathrm{~h}$ of incubation exhibited a low cytotoxic effect on V79 cells, highlighting viability values of $81.83 \%(25 \mu \mathrm{g} / \mathrm{mL})$ and $65.39 \%(200 \mu \mathrm{g} / \mathrm{mL})$. The $48 \mathrm{~h}$ UBM extract treatment revealed an increase in cytotoxic effect in a dose-effect manner, the percent of living cells being $65.39 \%$ at $25 \mu \mathrm{g} / \mathrm{mL}$ and $30.96 \%$ at $200 \mu \mathrm{g} / \mathrm{mL}$. The $24 \mathrm{~h}$ incubation with UBE extract induced a viability of $81.36 \%(25 \mu \mathrm{g} / \mathrm{mL})$ and of $73.36 \%(200 \mu \mathrm{g} / \mathrm{mL})$, respectively. The 48-h treatment with UBE was followed by a decrease in the living cell, with a percentage of $69.21 \%(25 \mu \mathrm{g} / \mathrm{mL})$ and $30.23 \%(200 \mu \mathrm{g} / \mathrm{mL})$. The UBA extract determined, at $24 \mathrm{~h}$ incubation, small decreases in cell viability, reaching $74.85 \%(25 \mu \mathrm{g} / \mathrm{mL})$ and $61.67 \%$ $(200 \mu \mathrm{g} / \mathrm{mL})$ values.

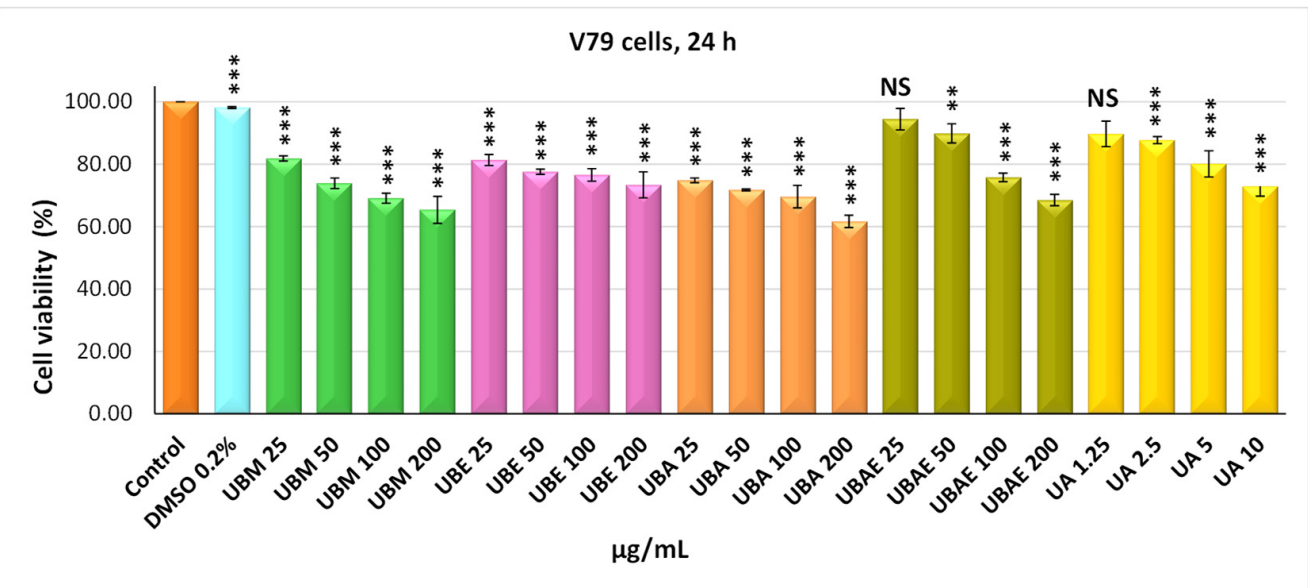

Figure 4. The viability of the V79 cells after treatment of $U$. barbata extracts $(\mu \mathrm{g} / \mathrm{mL})(24 \mathrm{~h})$. The results represent the mean $\pm \mathrm{SE}$ of three independent experiments $\left({ }^{* *} p<0.01,{ }^{* * *} p<0.001\right)$ when compared to the untreated control ( $t$-test).

Continuation of UBA treatment to $48 \mathrm{~h}$ led to moderate decreases in cell viability at the minimum dose (56.86\%) and significant decreases at the maximum dose (25.38\%). Finally, the UBEA extract, similar to the other extracts after $24 \mathrm{~h}$ of treatment, determined moderate cytotoxicity on V79 fibroblasts of $94.43 \%(25 \mu \mathrm{g} / \mathrm{mL})$ and $68.48 \%(200 \mu \mathrm{g} / \mathrm{mL})$. The cell viability showed a gradual decrease with increasing dose after $48 \mathrm{~h}$ of UBEA extract treatment, $60.98 \%$ at $25 \mu \mathrm{g} / \mathrm{mL}$ and $36.83 \%$ at $200 \mu \mathrm{g} / \mathrm{mL}$ (Figure 5).

In the case of both cell lines, it was found that DMSO $0.2 \%$, in which the $U$. barbata extracts were dissolved, is non-toxic, registering values of cell viability very close to those of the untreated control.

The cytotoxic activity of $U$. barbata extracts was better illustrated by $\mathrm{IC}_{50}$ values, meaning the concentration at which the studied extracts exert half of the maximal inhibitory effect. The results confirmed that the strongest antitumor effect against cancer CAL-27 cells had the UBA extract, with an $\mathrm{IC}_{50}$ value of $37.34 \mu \mathrm{g} / \mathrm{mL}$, followed by UBEA, with an $\mathrm{IC}_{50}$ value of $56.78 \mu \mathrm{g} / \mathrm{mL}$, UBM with $\mathrm{IC}_{50}$ value of $60.18 \mu \mathrm{g} / \mathrm{mL}$, and finally UBE, with an $\mathrm{IC}_{50}$ value of $75.79 \mu \mathrm{g} / \mathrm{mL}$. The average half-maximal inhibitory concentration 
$\left(\mathrm{IC}_{50}\right)$ values were estimated in the case of normal V79 fibroblasts were approximately two times higher than cancer cells: UBA IC $50=54.89 \mu \mathrm{g} / \mathrm{mL}, \mathrm{UBM} \mathrm{IC}_{50}=123.35 \mu \mathrm{g} / \mathrm{mL}$, UBE IC $_{50}=126.22 \mu \mathrm{g} / \mathrm{mL}$, and UBEA IC $50=140.13 \mu \mathrm{g} / \mathrm{mL}$. Skehan et al. (1990) reported that NCI (US National Cancer Institute) has established three cytotoxicity groups for crude extracts obtained from natural sources: inactive extracts $\left(\mathrm{IC}_{50}>100 \mu \mathrm{g} / \mathrm{mL}\right)$, moderately active ( $\mathrm{IC}_{50} 20-100 \mu \mathrm{g} / \mathrm{mL}$ ), and active ( $\mathrm{IC}_{50}<20 \mu \mathrm{g} / \mathrm{mL}$ ) [83]. The $\mathrm{IC}_{50}$ values of the $U$. barbata extract on the cancer line were between 20 and $100 \mu \mathrm{g} / \mathrm{mL}$; hence all the extracts were moderately active according to $\mathrm{NCI}$ and were about two times less active in the healthy V79 cell line, meaning a slightly differentiated cytotoxic effect between the tumor and normal cells.

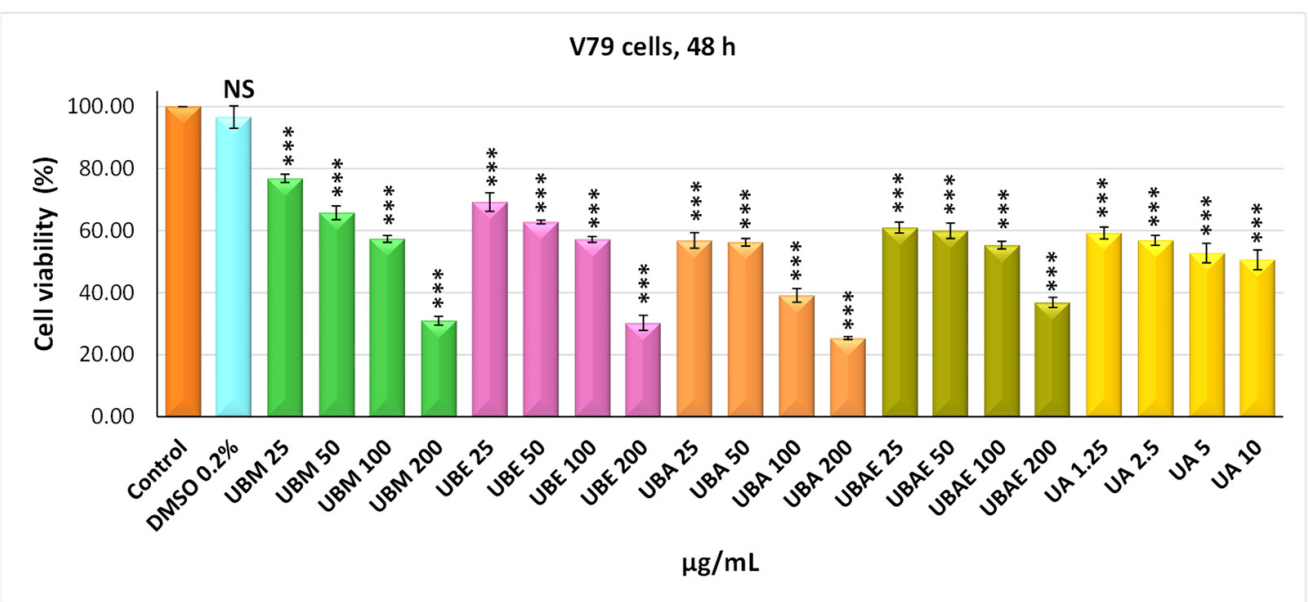

Figure 5. The viability of the V79 cells after $U$. barbata extracts $(\mu \mathrm{g} / \mathrm{mL})$ treatment $(48 \mathrm{~h})$. The results represent the mean $\pm \mathrm{SE}$ of three independent experiments $(* * *<0.001)$ when compared to the untreated control ( $t$-test).

\subsection{Cell Morphology Assay}

Carreño et al. (2021) highlighted that the MTT assay could only distinguish viable cells from either senescent and dead cells, but not between senescent and dead cells, because senescent cells may continue transforming MTT to formazan. They indicated that microscopic observations, like cell detachment (in adherent cell lines) and the presence of cell fragments, are essential to confirm cellular toxicity [84]. Thus, the cytotoxicity of $U$. barbata extracts was also evaluated by analysis of the cells' shape and morphology after $24 \mathrm{~h}$ and $48 \mathrm{~h}$ treatment. As shown in Figures 6 and 7, the morphological characteristics of the cells were affected both depending on the solvent used but, especially on the duration of the treatment and the concentration of the tested extracts. Hence, cell adhesion, the ability to form the monolayer, and the integrity of the cell membrane were altered. In addition, cells displayed membrane shrinkage, cell vacuolization, many cell fragments, and reduction of cellular density by the accumulation of dead cells that floated in the growth medium.

In the normal V79 cell line, the intensity of cell response to the $U$. barbata extract application was lower than in CAL-27 cancer cells (Figures 8 and 9). In both cell lines, the accumulation of the floating cells by losing adhesion ability, membrane shrinkage, and formation of abnormal cellular wrinkle occurred. These cell morphological changes led to a reduction in the cell viability but revealed a selective cytotoxic effect of the extracts. 
CAL-27 - Cell morphology after 24 hours treatment
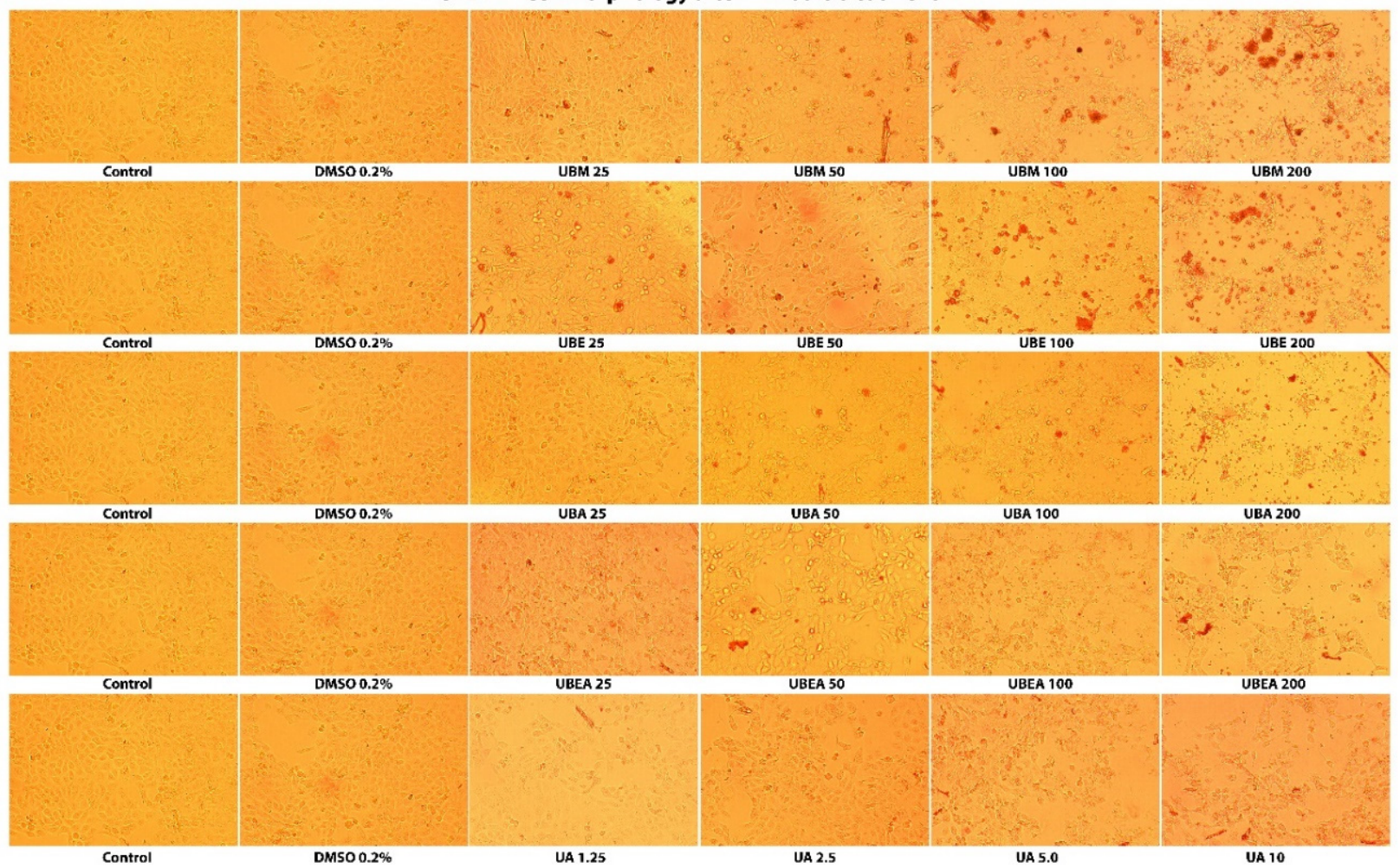

Figure 6. The morphology of the tumor CAL-27 cells after $24 \mathrm{~h}$ contact of the $U$. barbata extracts. The images were captured using an inverted microscope and $10 \times$ objective.

\section{CAL-27 - Cell morphology after 48 hours treatment}
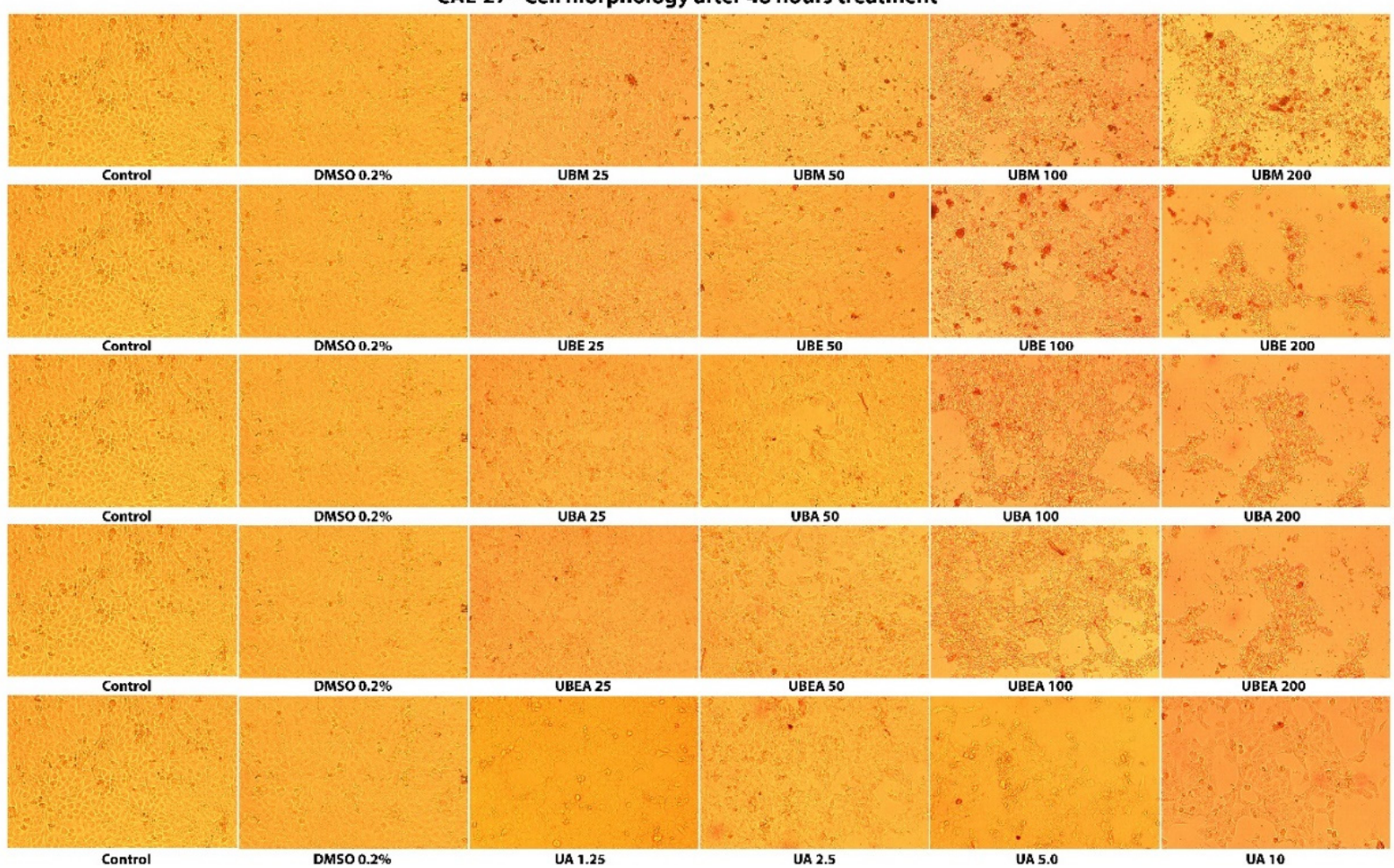

Figure 7. The morphology of the tumor CAL-27 cells after $48 \mathrm{~h}$ contact of the $U$. barbata extracts. The images were captured using an inverted microscope and $10 \times$ objective. 
v79 - Cell morphology after 24 hours treatment

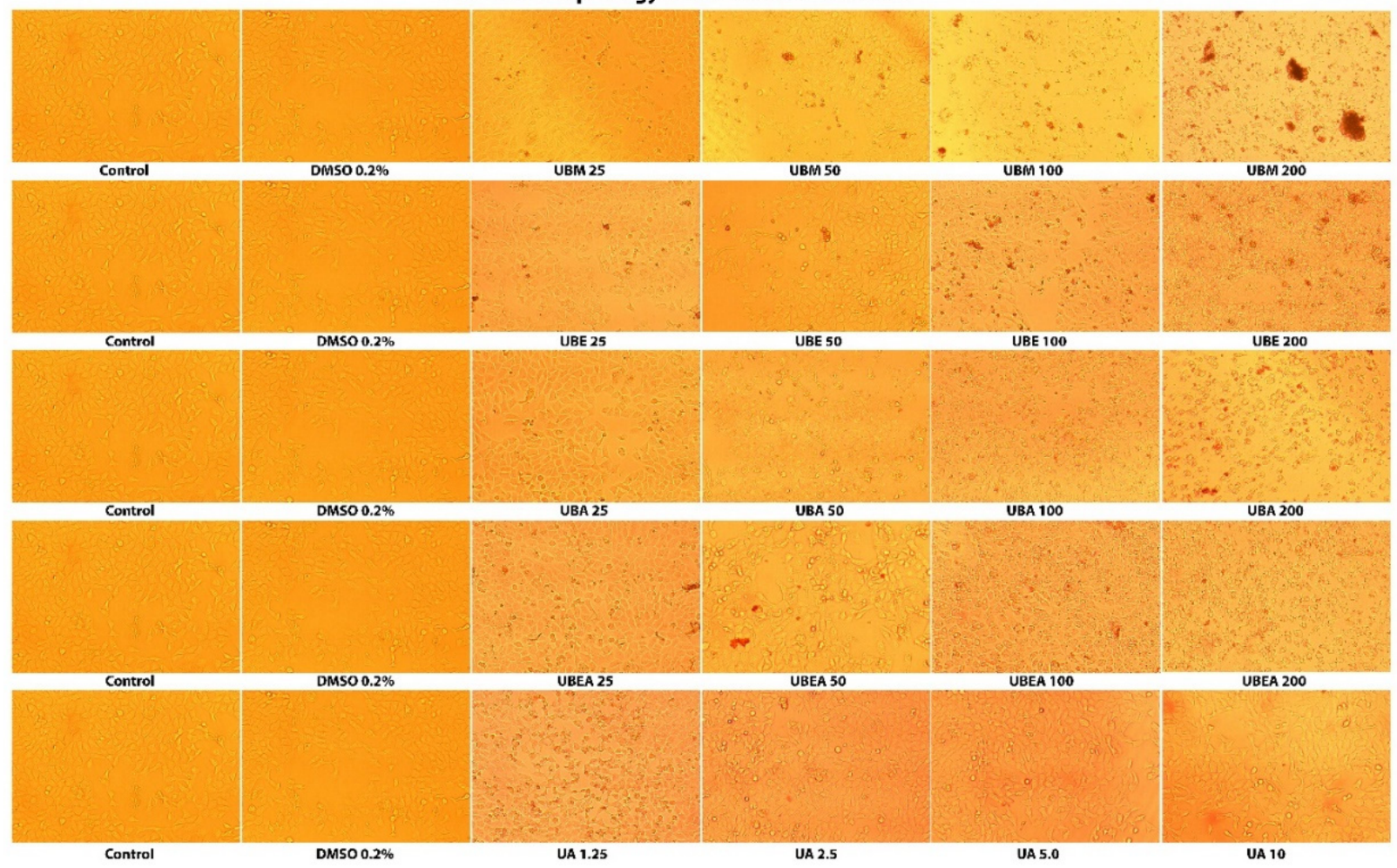

Figure 8. The morphology of the normal V79 cells after $24 \mathrm{~h}$ contact of the $U$. barbata extracts. The images were captured using an inverted microscope and $10 \times$ objective.
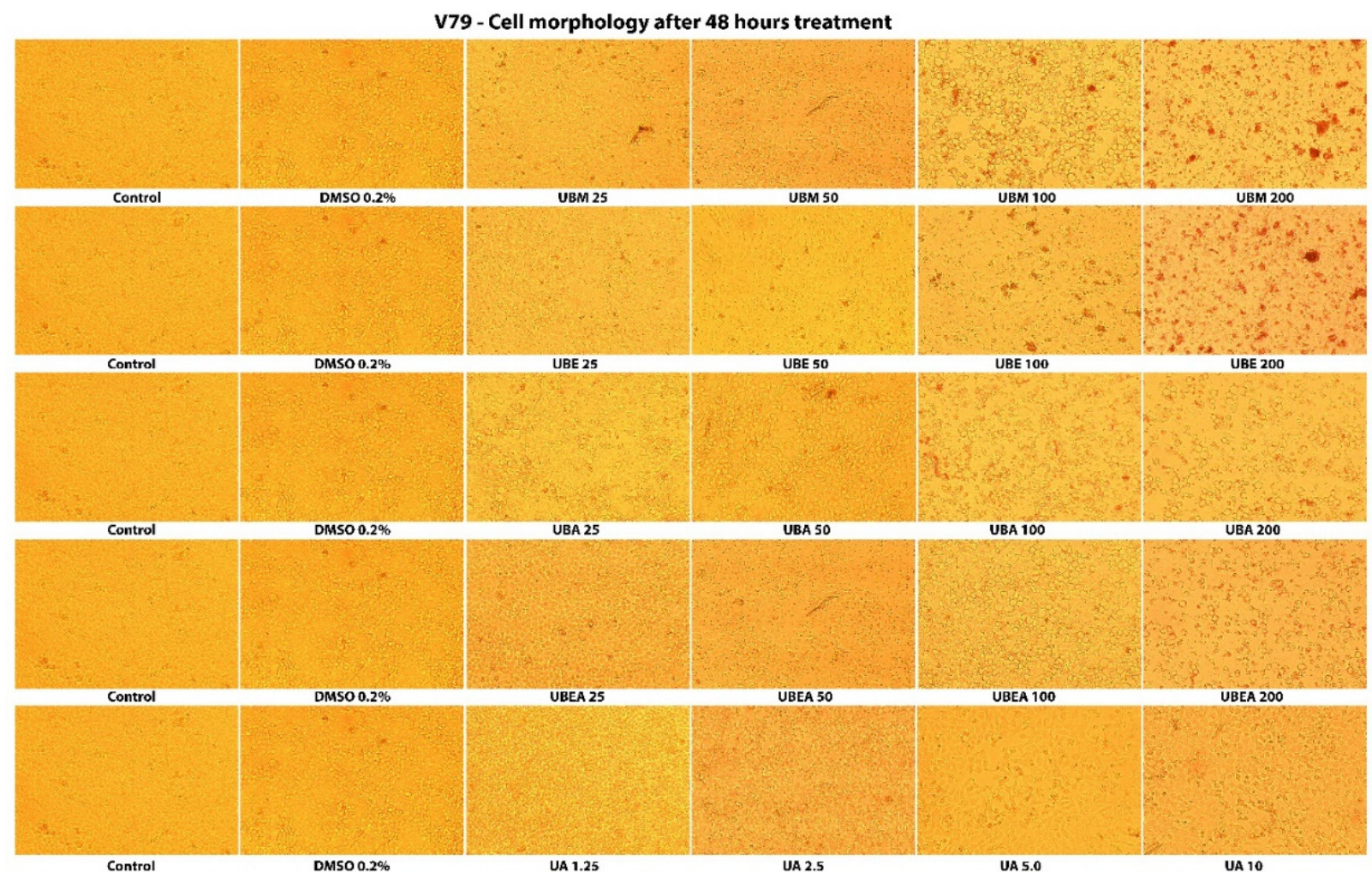

Figure 9. The morphology of the normal V79 cells after $48 \mathrm{~h}$ contact of the $U$. barbata extracts. The images were captured using an inverted microscope and $10 \times$ objective. 


\subsection{In Vitro Wound Healing Assay}

Because cell migration plays a major role in the cancer metastasis process, we applied the in vitro wound healing test using the CAL-27 tumor cell line and the V79 normal cell line in order to establish the selective wound closure property for each of the four $U$. barbata dry extracts, compared to the untreated control and DMSO used as the vehicle control. For both cell lines, wound closure evaluation was performed until healing was completed in the untreated control. As shown in Figure 10, after $24 \mathrm{~h}$, the wound closure rate in the CAL-27 cell line ranged from $36.82 \%$ (control) to $6.51 \%$ (UBE). The lowest healing processes were maintained after $48 \mathrm{~h}$ in the UBE extract treatment, the dimension of wound edges representing $75.78 \%$ of the $\mathrm{T} 0$ value. The complete wound closure was achieved after $96 \mathrm{~h}$ for both the control and $0.2 \%$ DMSO variant. At this time, the wound closure was almost complete in all extracts, being between $76.60 \%$ (UBA) and $94.43 \%$ (UBEA) compared to the control. In addition, the usnic acid was effective in promoting wound healing, reaching a $96.07 \%$ rate of wound closure. Among all the tested $U$. barbata extracts, the widest wound edges were registered for the acetone (UBA) and methanol (UBM) extract at the $\mathrm{IC}_{50}$ value, proving a potential inhibitory effect on metastatic progression (Figures 10 and 11).

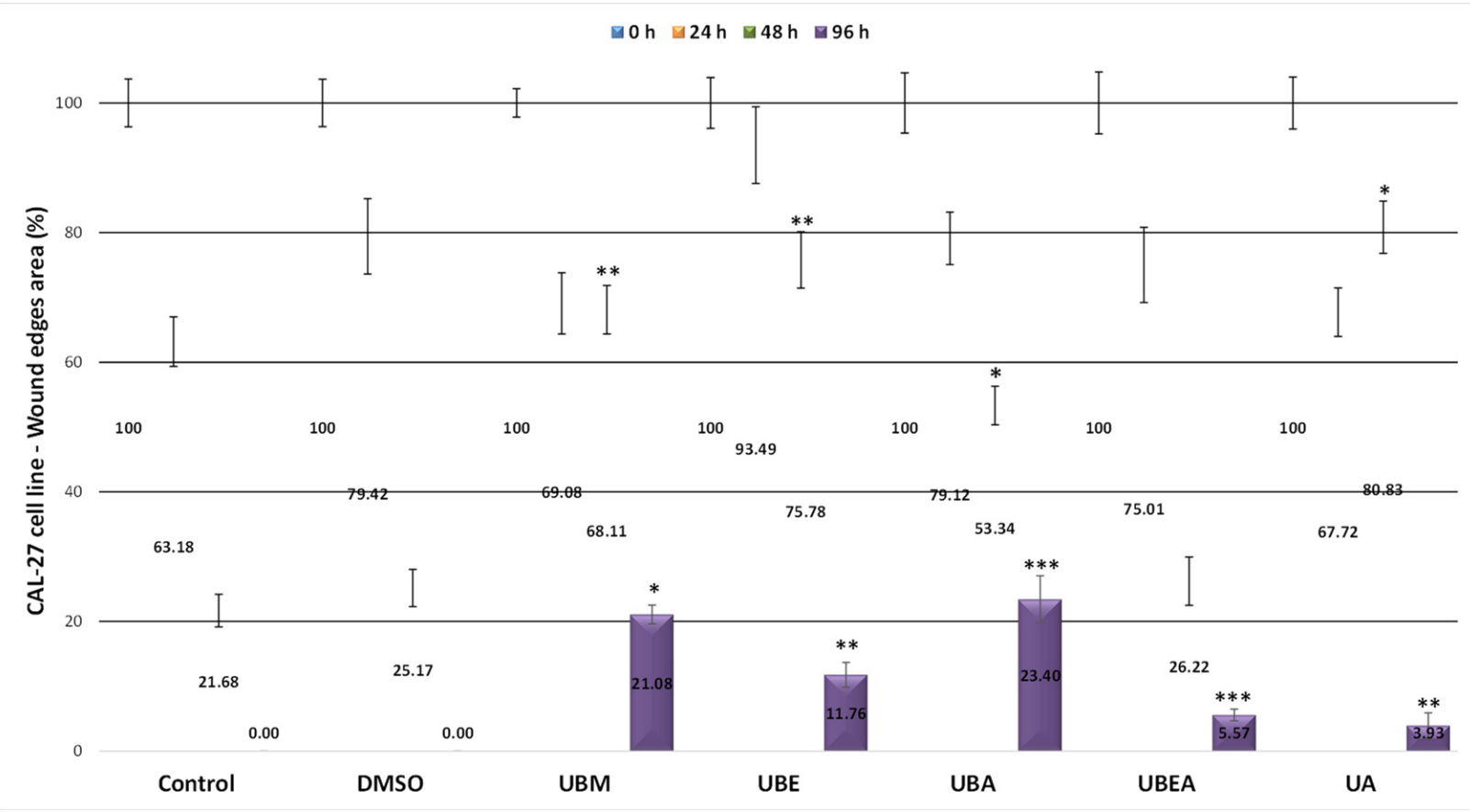

Figure 10. The effect of $U$. barbata extracts on the tumor CAL-27 cell migration process assessed by the in vitro scratch wound assay. The results represent the means $\pm \mathrm{SD}$ of three independent experiments. The results represent the mean $\pm \mathrm{SE}$ of three independent experiments $\left({ }^{*} p<0.05,{ }^{* *} p<0.01,{ }^{* * *} p<0.001\right)$ when comparing the untreated control ( $t$-test).

The cell progression and migration rate for wound closure was faster for the V79 cells than the CAL-27 cell line; the complete wound closure for the control and 0.2\% DMSO was established at $48 \mathrm{~h}$ from scratch initiation. As shown in Figures 12 and 13, after $24 \mathrm{~h}$, the control scratch area was covered by the cells in the percentage of $87.14 \%$, where the highest percentage of wound closure was encountered at the UBEA extract $(63,85 \%)$, and the lowest healing capacity was established after exposure to the UBA extract (38.15\%). 


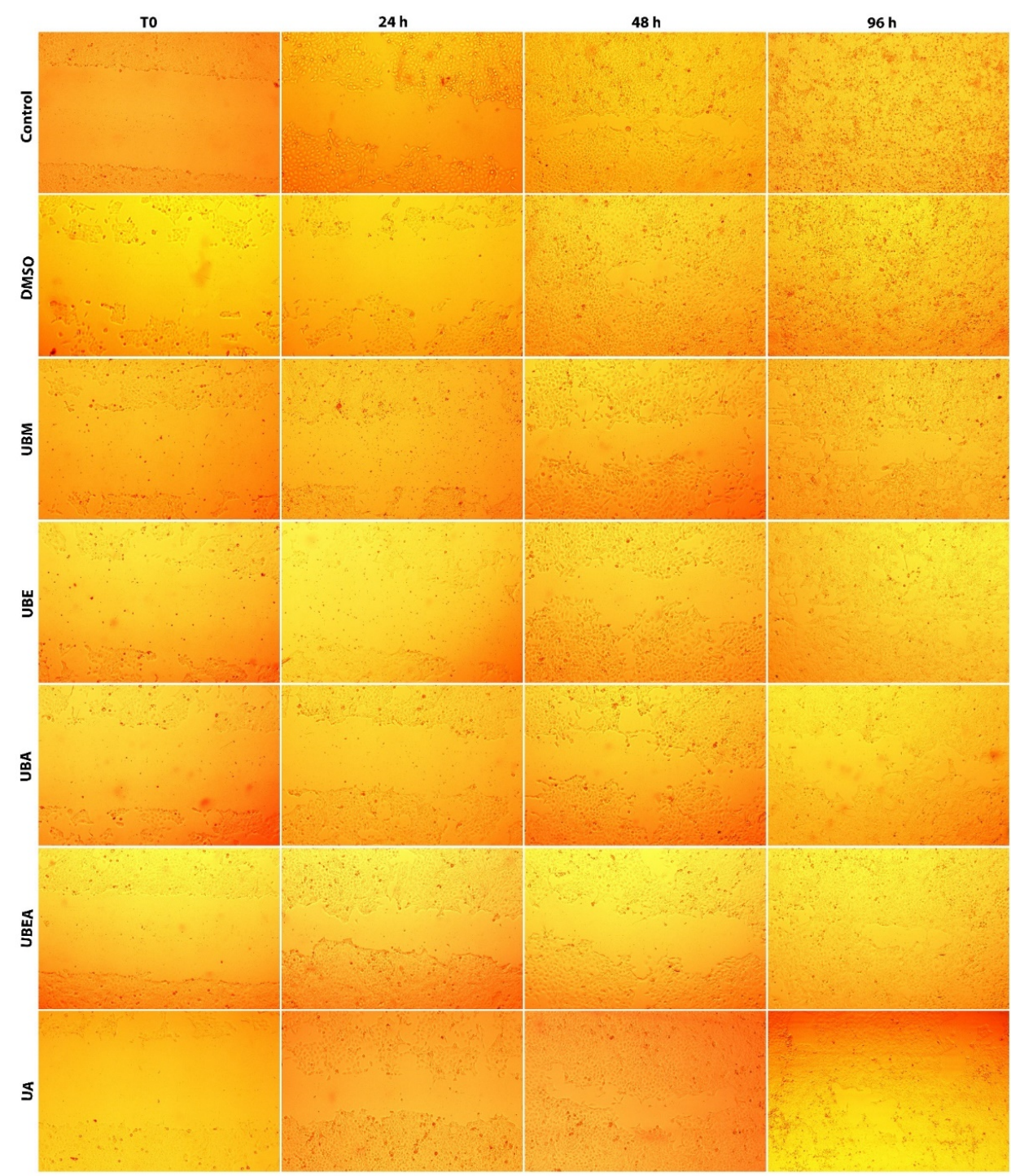

Figure 11. Microscopic images representing the in vitro wound healing process of tumor CAL-27 cells after treatment of $U$. barbata extracts using $\mathrm{IC}_{50}$ doses.

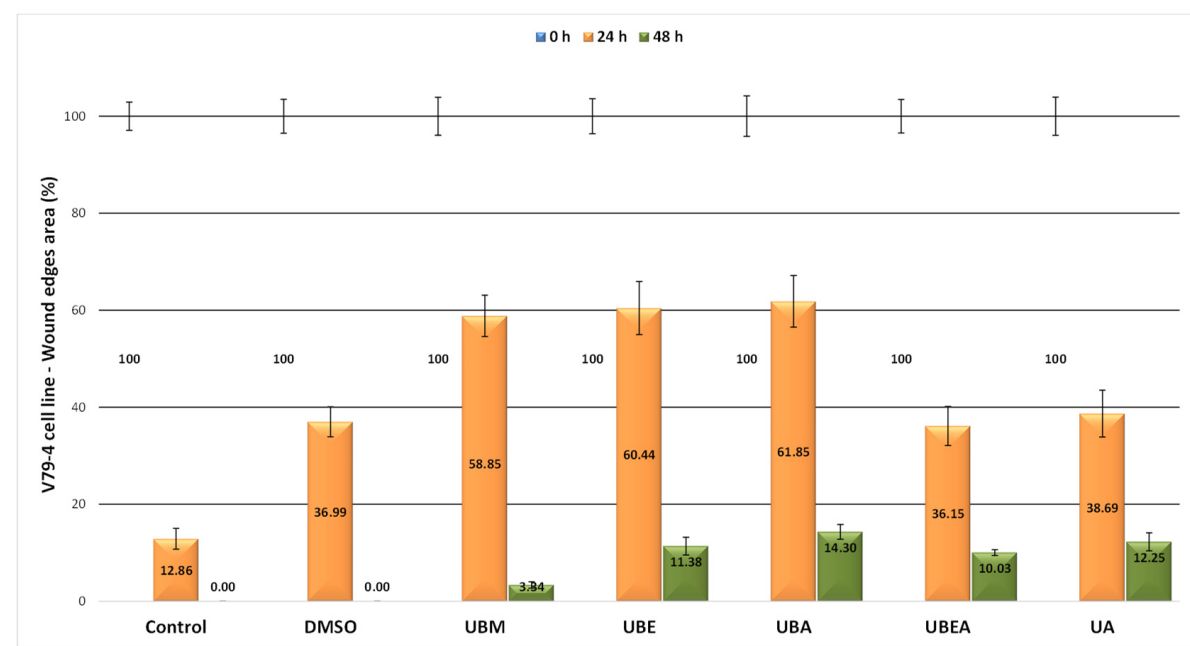

Figure 12. The effect of $U$. barbata extracts on the normal V79 cell migration process assessed by the in vitro scratch wound assay. The results represent the means \pm SD of three independent experiments. 


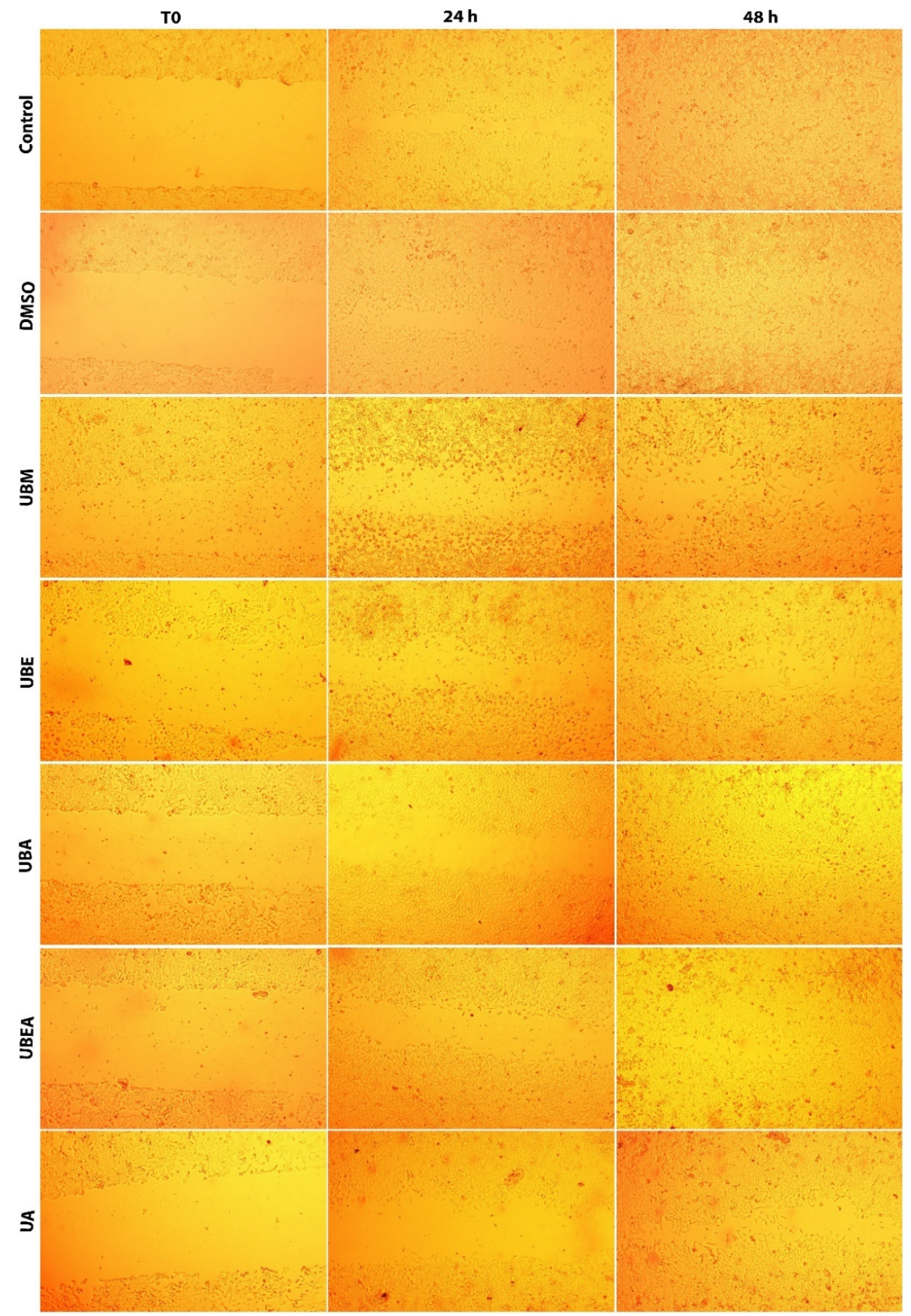

Figure 13. Microscopic images represent the in vitro wound healing process of normal V79 cells after treatment of $U$. barbata extracts using $\mathrm{IC}_{50}$ doses.

Prolonging the treatment time, the migration rate at $48 \mathrm{~h}$ after the application of $U$. barbata extracts was between $85.70 \%$ (UBA) and $96.66 \%$ (UBM). Among all $U$. barbata extracts, the highest sensitivity of the V79 cell line was also established after the UBA extract treatment, similar to the CAL-27 cell line response, but in a reduced manner. These results could prove the high tolerability and selectivity of the tested $U$. barbata dry extracts upon the normal V79 cell line. 


\subsection{Clonogenic Assay}

Our studies focused on assessing whether the four $U$. barbata extracts obtained using different solvents had long-term action on survival and cell proliferation. The clonogenic assay was performed for both the CAL-27 tumor cell line and normal V79 cells treated with the $\mathrm{IC}_{50}$ established for each extract. As shown in Figure 14a, the clonogenic potential of the CAL-27 cells was significantly inhibited after the application of the extracts. The lowest percent of colony formation was exerted by UBA (12.24\%), followed by UBEA, UBE, and UBM. The $0.2 \%$ DMSO vehicles showed similar colony development like the untreated control. In the V79 cell line, the survival potential was less than $50 \%$ only in UBE exposure $(43.26 \%)$. More than $90 \%$ ability of colony formation was obtained after UBA treatment (Figure 14b). For both cell lines, standard usnic acid (UA) had no toxic effect on colony formation, with the survival fraction reaching $97.96 \%$ in the CAL-27 cells and $98.58 \%$ in the V79 cells, respectively.

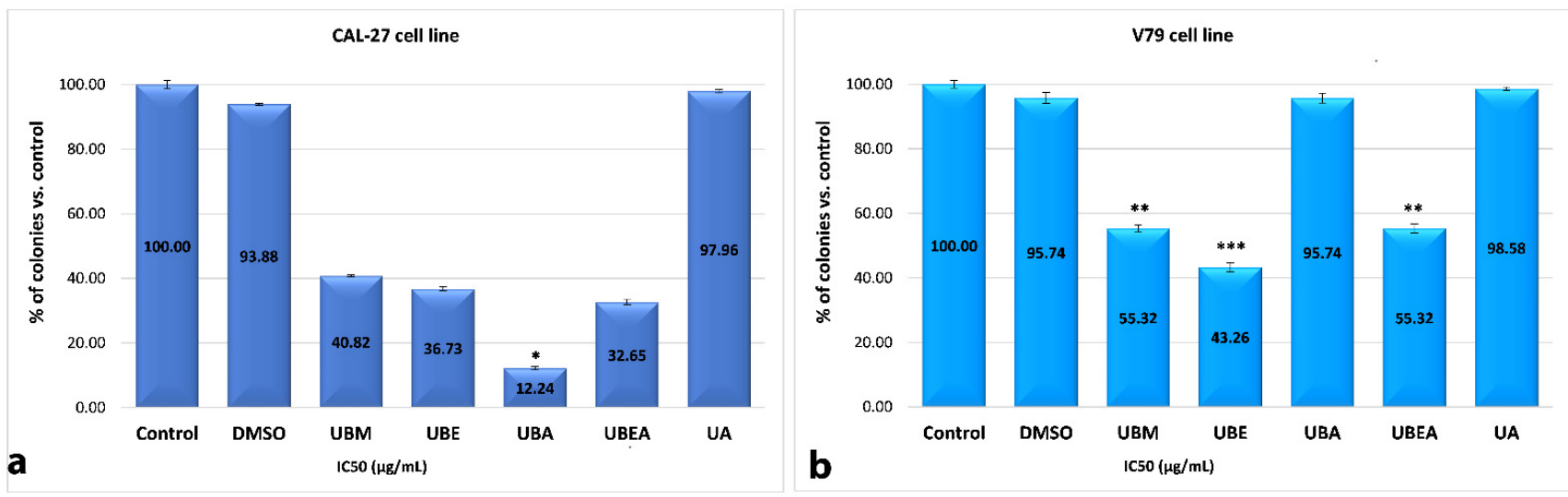

Figure 14. Effect of $U$. barbata extracts on the colony formation of cancer CAL-27 cell line (a) and normal V79 cells (b) cultivated in 24-well plates in triplicate. All data represent the mean \pm SE compared to the control. ${ }^{* *} p<0.0,{ }^{* * *} p<0.001, t$-test.

\subsection{Antioxidant Enzymes Activity Assay}

The effect of $U$. barbata extracts on some oxidative stress biomarkers such as the activity of the main antioxidant enzymes, SOD, CAT, and GPx as well as the level of (MDA) was investigated. The CAL-27 cancer cells and normal V79 cells were treated for $6 \mathrm{~h}$ with $\mathrm{IC}_{50}$ specific values of each $U$. barbata extract. A positive control was performed; the cells were treated for 15 min with $100 \mu \mathrm{M} \mathrm{H}_{2} \mathrm{O}_{2}$, then twice washed with PBS and trypsinized simultaneously as other treated groups to obtain the cell lysates used to estimate the mentioned oxidative stress biomarkers.

\subsubsection{Determination of Superoxide Dismutase Activity}

Superoxide dismutase, the first line of defense of cells against ROS generated by exposure to various agents, is the principal-agent for cleaning superoxide radicals, being a powerful antioxidant that converts the toxic superoxide anion $\left(\mathrm{O}_{2}{ }^{-}\right)$into hydrogen peroxide and oxygen by thee dismutation reaction: $2 \mathrm{O}_{2}+2 \mathrm{H}^{+} \rightarrow \mathrm{H}_{2} \mathrm{O}_{2}+\mathrm{O}_{2}$.

The impact of different $U$. barbata extracts after $6 \mathrm{~h}$-treatment with specific $\mathrm{IC}_{50}$ values on SOD activity in CAL-27 cells, expressed in units of SOD $/ \mathrm{mg}$ protein, is illustrated in Table 3 . SOD activity stimulation was observed by all four $U$. barbata extracts compared to the untreated control (considered $100 \%$ ), with the most active stimulation recorded by UBE $(212.76 \%)$, and the lowest one by UBA (180.04\%). In the case of the V79 normal cells, there was an inhibition of SOD activity for all $U$. barbata extracts, the smallest value was found at UBA $(40.49 \%)$, and the largest at UBM $(90.44 \%)$, compared with the untreated control $(100 \%)$, as seen in Table 4. 
Table 3. The activity of SOD, CAT, GPx, and MDA levels in CAL-27 cells after $\mathrm{IC}_{50} U$. barbata extract treatment.

\begin{tabular}{ccccc}
\hline & $\begin{array}{c}\text { U SOD/mg } \\
\text { Protein }\end{array}$ & $\begin{array}{c}\text { U CAT/mg } \\
\text { Protein }\end{array}$ & $\begin{array}{c}\text { U GPx/mg } \\
\text { Protein }\end{array}$ & $\begin{array}{c}\text { MDA (mM/mg } \\
\text { Protein) }\end{array}$ \\
\hline Control & $0.432 \pm 0.065$ & $3.452 \pm 0.058$ & $0.00116 \pm 0.0001$ & $11.694 \pm 0.309$ \\
DMSO 0.2\% & $0.803 \pm 0.121^{*}$ & $3.115 \pm 0.143$ & $0.00116 \pm 0.0000$ & $8.194 \pm 0.599 * *$ \\
UBM & $0.788 \pm 0.124$ & $3.605 \pm 0.093$ & $0.00136 \pm 0.0000^{*}$ & $10.302 \pm 1.758$ \\
UBE & $0.917 \pm 0.133^{*}$ & $2.292 \pm 0.095^{* * *}$ & $0.00134 \pm 0.0000^{*}$ & $10.674 \pm 2.163$ \\
UBA & $0.777 \pm 0.217$ & $3.119 \pm 0.103 *$ & $0.00123 \pm 0.0000$ & $8.180 \pm 0.602^{* *}$ \\
UBEA & $0.807 \pm 0.153$ & $3.110 \pm 0.225$ & $0.00133 \pm 0.0000^{*}$ & $9.518 \pm 1.377$ \\
UA & $0.890 \pm 264$ & $3.395 \pm 0.216$ & $0.00144 \pm 0.0000$ & $10.205 \pm 0.519$ \\
$\mathrm{H}_{2} \mathrm{O}_{2} 100 \mu \mathrm{M}$ & $1.307 \pm 0.04^{* * *}$ & $3.897 \pm 0.269$ & $0.00146 \pm 0.0001^{* *}$ & $9.159 \pm 0.532^{* *}$ \\
\hline
\end{tabular}

The results represent the mean \pm SE of the three independent experiments compared to the effects obtained in the untreated control (t-test); ${ }^{*} p<0.05 ;{ }^{* *} p<0.01 ;{ }^{* * *} p<0.001$.

Table 4. The activity of SOD, CAT, GPx, and MDA levels in the V79 cells after $\mathrm{IC}_{50}$ U. barbata extract treatment.

\begin{tabular}{ccccc}
\hline & $\begin{array}{c}\text { U SOD/mg } \\
\text { Protein }\end{array}$ & $\begin{array}{c}\text { U CAT/mg } \\
\text { Protein }\end{array}$ & $\begin{array}{c}\text { U GPx/mg } \\
\text { Protein }\end{array}$ & $\begin{array}{c}\text { MDA (mM/mg } \\
\text { Protein) }\end{array}$ \\
\hline Control & $0.969 \pm 0.081$ & $2.9547 \pm 0.035$ & $0.0015 \pm 0.0000$ & $10.150 \pm 0.492$ \\
DMSO 0.2\% & $0.774 \pm 0.036$ & $2.1940 \pm 0.305^{* *}$ & $0.0017 \pm 0.0001$ & $9.177 \pm 0.837$ \\
UBM & $0.876 \pm 0.071$ & $1.4983 \pm 0.059^{* * *}$ & $0.0020 \pm 0.0000^{* * *}$ & $8.802 \pm 0.378$ \\
UBE & $0.609 \pm 0.050^{* *}$ & $1.9495 \pm 0.102^{* * *}$ & $0.0018 \pm 0.0000^{* *}$ & $7.631 \pm 0.065^{* *}$ \\
UBA & $0.393 \pm 0.060^{*}$ & $2.6878 \pm 0.185$ & $0.0015 \pm 0.0001$ & $9.555 \pm 0.221$ \\
UBEA & $0.872 \pm 0.108$ & $1.4831 \pm 0.270^{* * *}$ & $0.0017 \pm 0.0000$ & $9.871 \pm 0.882$ \\
UA & $0.555 \pm 0.110^{*}$ & $0.4497 \pm 0.242^{* * *}$ & $0.0017 \pm 0.0001$ & $7.917 \pm 0.240^{*}$ \\
$\mathrm{H}_{2} \mathrm{O}_{2} 100 \mu \mathrm{M}$ & $1.017 \pm 0.124$ & $3.2741 \pm 0.341$ & $0.0020 \pm 0.0001 * *$ & $9.016 \pm 0.876$ \\
\hline
\end{tabular}

The results represent the mean \pm SE of the three independent experiments compared to the effects obtained in the untreated control $\left(t\right.$-test); ${ }^{*} p<0.05 ;{ }^{* *} p<0.01 ;{ }^{* * *} p<0.001$.

\subsubsection{Determination of Catalase Activity}

Catalase, an essential enzyme with the role of detoxifying ROS in all aerobic organisms, catalyzes the conversion of toxic $\mathrm{H}_{2} \mathrm{O}_{2}$, resulting from the dismutation reaction of SOD, in $\mathrm{H}_{2} \mathrm{O}$ and $\mathrm{O}_{2}$, in peroxisomes. SOD and CAT are complementary in their action to reduce the effects of oxidative stress. The increase in CAT activity indicates an increased capacity of this enzyme to eliminate the reactive species formed; it is an efficient purifier of $\mathrm{H}_{2} \mathrm{O}_{2}$ with a high affinity to the substrate.

The interference of 6 -h treatment with particular $\mathrm{IC}_{50}$ values of $U$. barbata extracts, with the activity of CAT expressed in units of U CAT/mg protein, in CAL-27 cells, was followed by a decrease in enzymatic activity, except in the UBM extract, which registered a slight increase in CAT activity (104.43\%). The lowest activity of CAT activity was registered in the UBE extract (66.36\%) compared to the control (100\%), as shown in Table 2. A similar trend was found in normal V79 cells. The decrease in the enzymatic activity of CAT under $U$. barbata extracts had a higher amplitude than the CAL-27 cancer cells. Thus, the most potent inhibitory action of CAT was UBEA (50.2\%) and the weakest was UBA (90.96\%) compared to the control $(100 \%)$, as illustrated in Table 3.

\subsubsection{Determination of Glutathione Peroxidase Activity}

Glutathione peroxidase catalyzes the decomposition of hydrogen peroxide $\left(\mathrm{H}_{2} \mathrm{O}_{2}\right)$ with reduced glutathione as a reducing agent, resulting in oxidized glutathione (G-S-S-G) and water. The activity of GPx was expressed in U GPx/mg protein.

Treatment with $U$. barbata extracts in CAL-27 cancer cells leads to slight increases in GPx activity compared to the control group, the highest activity being found in UBM $(117.7 \%)$ and the lowest in UBA (106.21\%), as shown in Table 2. In addition, in normal V79 cells, stimulation of GPx activity was registered, the highest value also being found in the 
UBM extract (128.55\%) compared with the untreated control (100\%). An exception was reported for the UBA extract, which caused an inhibitory effect on GPx activity (95.9\%), as rendered by Table 3 .

\subsubsection{Determination of Malondialdehyde levels}

MDA is a lipid peroxidation product, representing an important indicator of oxidative damage of macromolecules induced by ROS.

The effect of $U$. barbata extracts on redox status, especially on lipid peroxidation in the two cancer and normal cell lines, was quantified by measuring the changes in the MDA levels, as illustrated in Tables 2 and 3.

CAL-27 cancer cells showed a decrease in MDA levels, especially after exposure to UBA, reaching the value of $69.94 \%$ compared to the untreated control, considered as $100 \%$. The level of MDA was the least affected by UBE compared to the control (100\%), when a $91.29 \%$ value was recorded. The same trend was also observed in the case of V79 normal cells of MDA level decrease, but of different amplitudes. The most significant negative impact was determined by UBE (75.17\%), and UBEA affected MDA level the least $(97.24 \%)$ when compared with the control $(100 \%)$.

Our experimental results, comparable to those in the literature, through evaluation of the $U$. barbata extracts' action on oxidative stress biomarkers, suggest their targeted interaction with the complex chain of cellular redox processes so that the increase antioxidant enzyme activity and decrease in MDA level in CAL-27 cancer cells can lead to an imbalance in antioxidant defense mechanisms, with a tendency toward prooxidants, a substrate for the cytotoxic effect, while in normal V79 cells was observed an antioxidant effect, which protects normal cells against free radicals.

\section{Discussion}

The phytochemical profile of $U$. barbata is already known; Salgado et al. (2018) identified a wide range of secondary metabolites in a methanol extract [85]. The metabolomics of this species belongs to different classes of chemical compounds: depsides (barbatic acid, methyl-8-hydroxy-4-O-demethylbarbatate, baeomycesic acid, 8-hydroxybarbatic acid), depsidones (connorstictic acid, fumarprotocetraric acid, hypoconstictic acid, lobaric acid), lipids (polyhydroxylated lipids), and dibenzofurans (usnic acid, placodiolic acid) On the other hand, in an acetone extract of U. longissima, Reddy et al. (2019) reported another dibenzofuran compound, usenamine $\mathrm{A}$, with the $-\mathrm{NH}_{2}$ group [86]. Of all these lichen secondary metabolites, usnic acid is by far the best known and responsible for most bio-activities of $U$. barbata, and at the same time, of all lichens of the Usnea genus.

The characteristics of the $\mathrm{OH}$ group's absorption band at $3200 \mathrm{~cm}^{-1}$ can be attributed to classes of compounds such as depside, depsidones, and dibenzofurans with $\mathrm{OH}$ phenolic.

Placodiolic and usnic acid, being characteristic of the studied species, may be related to this absorption band, a connection strengthened by the presence of the characteristic band for the carbonyl group $\mathrm{C}=\mathrm{O}$ around $1700 \mathrm{~cm}^{-1}$.

All extracts were identified as single $\mathrm{C}-\mathrm{H}$ bonds $\left(2918\right.$ and $\left.2850 \mathrm{~cm}^{-1}\right)$ and double $\mathrm{C}=\mathrm{C}$ bonds present in an aromatic nucleus (approximately $1629 \mathrm{~cm}^{-1}$ ), most likely belonging to aromatic acids.

No triple-bonds were found in any extract.

The characteristic band of lactones $\left(1736 \mathrm{~cm}^{-1}\right)$ has been identified in an ethyl acetate extract, a class of compounds that frequently occurs in lichens. If their presence in the extract is confirmed, it could mean that ethyl acetate is a suitable solvent for lactone extraction. Both previously mentioned studies reported several compounds with a lactone ring: lobaric acid ( $\delta$-lactone) and both usnic and placodiolic acid ( $\gamma$-lactone). Moreover, our previous study proved that the ethyl acetate extract had the highest usnic acid content [61].

The acetone extract shows the absorption band characteristic for $\mathrm{N}-\mathrm{H}$ aromatic secondary amine at $3448 \mathrm{~cm}^{-1}$ as a distinctive extraction pattern. This specific band could be associated with usenamine $\mathrm{A}$, as previously mentioned. 
Kondratiuc et al. (2015) optimized a protein extraction method from U. antarctica [87]. Belonging to the same Usnea genus, we can correlate the existence of the corresponding $\mathrm{C}=\mathrm{O}$ amide band at $1572 \mathrm{~cm}^{-1}$ with protein structures in the $U$. barbata acetone extract.

Finally, it could be observed that all $U$. barbata extracts showed a high grade of matching in the $4000-1500 \mathrm{~cm}^{-1}$ region, but with visible differences in intensities.

Diverse species of lichens fulfill numerous functions in traditional medicine, the food industry, the perfume industry, and dyes [88]. Mostly, the cell-killing effect of different lichen extracts has gained attention in the treatment of several types of cancer, as some studies have shown [48,89-91]. In the present study, we investigated the anticancer effect and possible mechanism of action of $U$. barbata extracts against oral cancer CAL-27 cells. The role of preferential killing cells, morphological characteristics, wound healing property, clonogenic capacity, and antioxidant enzyme activity in oral cancer after treatment with $U$. barbata extracts are discussed below.

A recent study investigated the cell-killing property of methanol extracts of $U$. barbata (MEUB) against oral cancer cells (Ca9-22, OECM-1, CAL 27, HSC3, and SCC9), showing preferential killing versus these cancer cell lines but rarely affecting normal oral cell lines (HGF-1). Ca9-22 and OECM-1 cells display the highest sensitivity to MEUB [92].

Other studies have revealed that different extracts of various Usnea species induced cell killing effects against several types of cancer cells. Thus, the methanol extract of $U$. intermedia was cytotoxic upon MCF7, MDA-MB-231, A549, and H1299 cells ( $\mathrm{IC}_{50}$ values were 17.5, 3.0, 21.4, and $10.2 \mu \mathrm{g} / \mathrm{mL}$ in $72 \mathrm{~h}$ ATP assay) [93]. Another study found that the methanol extract of $U$. filipendula Stirt induced a cytotoxic effect against lung (A549, PC3), liver (Hep3B), and rat glioma (C6) cancer cells [94] where the $\mathrm{IC}_{50}$ values were 37.0, $32.9,60.5$, and $67.9 \mu \mathrm{g} / \mathrm{mL}$ in the $72 \mathrm{~h}$ ATP assay. Different extracts of $U$. barbata such as (E1) $\mathrm{CO}_{2}$ supercritical extract and (E2) ether fraction of Soxhlet extract, demonstrated cytotoxic action on mouse melanoma B16 and rat glioma $\mathrm{C} 6$ cells, their $\mathrm{IC}_{50}$ values being (E1) 31.21 vs. 58.20 and (E2) 43.40 vs. $69.10 \mu \mathrm{g} / \mathrm{mL}$, respectively, in an acid phosphatase assay at $24 \mathrm{~h}$ [95].

Three extracts of lichen $U$. undulata Stirt. ( $n$-hexane, acetone and methanol) were tested for cytotoxic activity on two human cancer cell lines (MCF-7, NCI-H460) using the sulforhodamine $\mathrm{B}$ (SRB) assay. The $n$-hexane extract manifested the highest inhibition activity, with $\mathrm{IC}_{50} 5.26 \pm 0.13 \mu \mathrm{g} / \mathrm{mL}$ for MCF-7 and $6.83 \pm 0.64 \mu \mathrm{g} / \mathrm{mL}$ for NCI-H460, followed by acetone extract with $\mathrm{IC}_{50} 66.44 \pm 1.37 \mu \mathrm{g} / \mathrm{mL}$ and $92.14 \pm 1.49 \mu \mathrm{g} / \mathrm{mL}$, respectively. The methanol extract showed a weak cytotoxic effect against MCF-7 and NCI-H460 (IC 50 values more than $100 \mu \mathrm{g} / \mathrm{mL}$ ). The $n$-hexane extract demonstrated cytotoxicity toward MCF-7 cells and low damage to normal fibroblasts, which means good selectivity [96].

The WST-1 assay for cell proliferation and viability evidenced that acetone extracts of Moroccan Evernia prunastri (E. prunastri), Ramalina farinacea (R. farinacea), and Pseudevernia furfuracea (P. furfuracea) showed moderate cytotoxic effects against human prostate cancer (22RV1), human colon carcinoma (HT-29), human hepatocellular carcinoma (Hep-G2), and hamster ovarian cancer $(\mathrm{CHO})$ cells lines, with $\mathrm{IC}_{50}$ values ranged from 42.30 to $140.24 \mu \mathrm{g} / \mathrm{mL}$ [93-95].

In the present study, $\mathrm{IC}_{50}$ values for the $U$. barbata dry extract-treated oral cancer CAL-27 cells for $48 \mathrm{~h}$ in the MTT assay were 37.34 (UBA), 56.78 (UBEA), 60.18 (UBM), and 75.79 (UBE) $\mu \mathrm{g} / \mathrm{mL}$, respectively. It can be seen that our $U$. barbata dry extracts exhibited a similar drug sensitivity to human oral cancer cells with extracts from another Usnea species to diverse cancer cells [95-98]. Compared with usnic acid (UA), used as a positive control, the $\mathrm{IC}_{50}$ value of UA in oral cancer CAL-27 was $8.34 \mu \mathrm{g} / \mathrm{mL}$ for the $48 \mathrm{~h}$ MTT assay, meaning that the studied $U$. barbata extracts contain enough usnic acid to induce antitumor activity, their lower sensitivity than that of UA being due to other compounds (polyphenols, tannins) from extracts.

While $U$. barbata extracts manifested a cytotoxic effect on the CAL-27 OSCC line, the healthy V79 cell line was about two times less active, meaning differentiated cytotoxicity between the tumor and normal cells, following other studies, where the cytotoxic activity 
of lichens was observed in different cancer cell lines. It has been noticed that their cytotoxic capacities in cancer cells are higher than in normal cells [53,99].

Lichens contain bioactive compounds that can be considered promising candidates for cell proliferation and migration, essential for tissue regeneration. Even if the extract of $U$. articulata is empirically administered to treat wounds and bruises [100], the in vitro studies regarding the wound healing ability are few and have been conducted in the last decade. Thus, Yang et al. (2016) mention an inhibition of migration invasion of A549 cell line after treatment with $U$. florida $(5 \mu \mathrm{g} / \mathrm{mL})$ acetone extract, the activity being due to some secondary metabolites such as depside, depsidone, dibenzofurans, and depsone [51]. On the other hand, the usnic acid derivates like sodium usnic acid may promote skin wound healing by increasing fibroblast proliferation [101]. Burlando et al. (2009) showed that the dibenzofuran derivative (+)-usnic acid polyketides compound (1) expressed wound healing at low doses against some malignant cell lines (MM98, A431) [102]. These results proved that this compound may be useful in the prevention of hyperproliferative syndromes. Furthermore, some usnic acid enamines (compounds 2-11) demonstrated, at subtoxic doses, the in vitro and in vivo wound closure of the keratinocytes, making them useful in healing-promoting and obtaining anti-aging skin formulations [103]. Our results are similar to the mentioned scientific literature: the four $U$. barbata extracts induced high toxicity in the CAL-27 oral cancer cell line, as the wound healing activity occurred slowly, and after $96 \mathrm{~h}$ of the treatment, the remaining wound area was between $23.40 \%$ (UBA), followed by UBM $(21.08 \%)$, and UBE $(11.76 \%)$. The intense effect on wound closure was established with UBEA treatment, and the wound area had a close value of $5.57 \%$ to the UA exposure (3.3\%).

The in vitro cell survival test assesses the ability of single cells to survive and proliferate to form colonies used to study the effects of some natural or synthetic compounds and also of radiation impact $[72,104]$. Our selectivity response between tumor and normal cells was similar to that of [105], who mentioned that atranorin (ATR), the common lichen secondary metabolites of Parmeliaceae, reduced the clonogenic potential of mouse breast cancer (4T1) cells compared to normal mammal non-malignant epithelial (NMuMG) cells. Guzow-Krzemińska et al. (2019) also tested some usnic acid derivates with high bioavailability and selectivity against cancer cells [106]. Thus, the UA compound has an inhibitory potential of clonogenic and cell survival on some breast cancer cells, but it is safe for non-tumorigenic MCF-10A mammary epithelial cells. Some syntheses of usnic acid derivatives have proven the significant inhibition of the clonogenic potential of MCF-7, HeLa, and PC-3 cancer cells [107].

Antioxidant enzymes such as glutathione peroxidases (GPx), catalases (CAT), and superoxide dismutases (SOD) catalyze the intracellular reduction of reactive oxygen species (ROS). Nevertheless, sometimes, antioxidant defense mechanisms are not enough to assure a redox balance that tilts toward prooxidants. The body develops oxidative stress, thus causing toxicity and genome impairment [108].

Lichens prevent mutagenesis and carcinogenesis through the inhibition of cellular macromolecule oxidation [109]. Therefore, the protective effects of lichens against oxidative impairment can be determined by monitoring the above-mentioned oxidative stress markers [110].

One of the most widely studied lichen compounds in pharmacological effects including its antioxidant potential is usnic acid (UA). UA determined increased levels of superoxide dismutase (SOD), glutathione peroxidase (GPx), and reduced glutathione (GSH) and reduced lipid peroxidation in gastric ulcer in rats [111]. Another study demonstrated that usnic acid protects astrocytes against hydrogen peroxide-induced oxidative stress by increasing cell viability and inhibiting intracellular ROS production; this action seems partially related to its peroxyl scavenger ability [112]. Usnic acid was also effective as an antioxidant agent against lipopolysaccharide-induced lung injury by decreasing the hydrogen peroxide, myeloperoxidase, and malondialdehyde levels and increasing the superoxide dismutase (SOD) and reduced glutathione (GSH) levels [113]. 
Against this background, our results regarding the effect of $U$. barbata extract on markers of oxidative stress are similar to those reported in other studies. Thus, UBA acetone and UBEA ethyl acetate extracts, which possessed the highest content of usnic acid (282.78 and $376.73 \mathrm{mg} \mathrm{UA} / \mathrm{g} U$. barbata extract, respectively) [61] and showed the most substantial cytotoxic effect on CAL-27 cancer cells, developed a prooxidant behavior, causing oxidative stress, and therefore a cytotoxic effect. Instead, in normal V79 cells, it induced an antioxidant effect, which protects normal cells against free radicals.

Finally, these four extracts of $U$. barbata in different solvents (methanol, ethanol, acetone, and ethyl acetate) could represent possible antitumor agents against cancer CAL-27 cells in a concentration- and time-dependent manner. Based on the MTT assay and IC 50 values, the most potent anticancer property was shown by acetone and ethyl acetate extracts, which had the highest content of usnic acid, responsible for the anticancer effect. The same extracts induced a prooxidant behavior in CAL-27 cancer cells, causing oxidative stress and thus a cytotoxic effect. In normal V79 cells, an antioxidant effect was determined, which protects normal cells against free radicals. All $U$. barbata extracts induced morphological modifications (losing adhesion property, membrane shrinkage, formation of abnormal cellular, vacuolization) of different amplitudes, correlated with the tested extract, the applied dose, and the cell line. The in vitro wound-healing assay revealed that the most powerful effect on wound closure was established after ethyl acetate extract exposure. The clonogenic test showed that certain extracts of $U$. barbata attenuated the ability of cancer cells to form colonies, thereby reducing the ability to form tumors.

\section{Conclusions}

The novelty of our study consists in the evaluation anticancer properties evaluation of four autochthonous $U$. barbata dry extracts in various solvents (methanol, ethanol, acetone, and ethyl acetate) and comparative analysis of the obtained results. Furthermore, their activities were examined on the CAL-27 tongue squamous carcinoma cell line and V79 normal cells, noting the differentiated cytotoxicity, higher in tumor cells than in normal ones. Another significant aspect supporting this statement is that our tests such as clonogenic, wound healing, and antioxidant enzymes activity assays regarding the $U$. barbata studied extracts, have rarely appeared in the previous research concerning the biological effects of lichens. In addition, relatively few antitumor studies have been performed on this OSCC cell line to analyze the previously mentioned processes.

The obtained data could enrich the existing information in the scientific databases, which must be constantly updated by in vitro screening of the bioactivities of $U$. barbata extracts as well as the usnic acid impact on both cell lines used in our study. Our results suggest that $U$. barbata dry extracts may exhibit anticancer pharmacological efficacy, providing multiple and specific targeting effects through a variety of secondary metabolites that they contain and could generate a synergism, a valuable property in cancer therapy.

Further research could explore the effect of $U$. barbata extracts against other cancer cell lines, also analyzing other crude extract constituents and evaluating their anticancer property. Moreover, deepening investigations regarding other mechanisms of action that express the cytotoxic effect in cancer cells could be helpful in considering the lichens from Romania as potential sources of antitumor drugs.

Supplementary Materials: The following are available online at https://www.mdpi.com/article/ 10.3390/antiox10071141/s1, Figure S1: U. barbata dry extracts. Figure S2: FTIR spectra of UBE; Figure S3: FTIR spectra of UBM; Figure S4: FTIR spectra of UBA; Figure S5: FTIR spectra of UBEA. Figure S6: FTIR spectra of usnic acid; Figure S7: Overlapping FTIR spectra of all $U$. barbata extracts.

Author Contributions: All authors contributed equally to this study and share first authorship. Conceptualization, V.P., G.V., D.G., C.T.M., D.R. and V.B.; Methodology, L.B., G.V., D.G., C.T.M., D.R. and S.I.C.; Software, G.V., D.G., C.T.M., D.R. and S.I.C.; Validation, G.V., D.G., T.C. and I.E.C.; Formal analysis, V.P., L.B. and V.B.; Investigation, E.M., F.C.B. and A.C.; Resources, V.P.; Data curation, V.P., G.V. and D.G.; Writing—original draft preparation, V.P., G.V. and D.G.; Writing-review and editing, V.P., G.V. and D.G., Visualization, V.P., G.V. and D.G.; Supervision, G.V. and D.G.; Project 
administration, V.B.; Funding acquisition, V.P. All authors have read and agreed to the published version of the manuscript.

Funding: This work was supported by the project ANTREPRENORDOC, in the framework of Human Resources Development Operational Program 2014-2020, financed from the European Social Fund under the contract number 36355/23.05.2019 HRD OP/380/6/13, SMIS Code: 123847.

Institutional Review Board Statement: The study approved by the Ethics Committee of Ovidius University of Constanta, Romania, 7080/10.06.2021.

Data Availability Statement: Data are contained within the article and supplementary materials.

Acknowledgments: This study was performed in collaboration with the Institute of Biological Research Iasi, branch of NIRDBS, 47 Lascar Catargi Street, 700107, Iasi, Romania, Research Center of Instrumental Analysis SCIENT, 1E Petre Ispirescu Street, 77167, Tancabesti, Ilfov, and Department of Pharmacognosy, Phytochemistry, and Center for Research and Development of the Morphological and Genetic Studies of Malignant Pathology, Ovidius University of Constanta, CEDMOG, 145 Tomis Blvd., 900591, Constanta, Romania This work was supported by the project ANTREPRENORDOC, in the framework of Human Resources Development Operational Program 2014-2020, financed from the European Social Fund under the contract number 36355/23.05.2019 HRD OP/380/6/13, SMIS Code: 123847.

Conflicts of Interest: The authors declare no conflict of interest.

\section{References}

1. Ferlay, J.; Colombet, M.; Soerjomataram, I.; Mathers, C.; Parkin, D.M.; Piñeros, M.; Znaor, A.; Bray, F. Estimating the global cancer incidence and mortality in 2018: GLOBOCAN sources and methods. Int. J. Cancer 2019, 144, 1941-1953. [CrossRef]

2. Patafio, F.M.; Brooks, S.C.; Wei, X.; Peng, Y.; Biagi, J.; Booth, C.M. Research output and the public health burden of cancer: Is there any relationship? Curr. Oncol. 2016, 23, 75. [CrossRef]

3. Markopoulos, A.K. Current Aspects on Oral Squamous Cell Carcinoma. Open Dent. J. 2012, 6, 126-130. [CrossRef] [PubMed]

4. Gordaliza, M. Natural products as leads to anticancer drugs. Clin. Transl. Oncol. 2007, 9, 767-776. [CrossRef]

5. Newman, D.J.; Cragg, G.M. Natural products as sources of new drugs over the 30 years from 1981 to 2010. J. Nat. Prod. 2012, 75, 311-335. [CrossRef] [PubMed]

6. Huang, H.L.; Wu, S.L.; Liao, H.F.; Jiang, C.M.; Huang, R.L.; Chen, Y.Y.; Yang, Y.C.; Chen, Y.J. Induction of apoptosis by three marine algae through generation of reactive oxygen species in human leukemic cell lines. J. Agric. Food Chem. 2005, 53, $1776-1781$. [CrossRef] [PubMed]

7. Nanni, V.; Canuti, L.; Gismondi, A.; Canini, A. Hydroalcoholic extract of Spartium junceum L. flowers inhibits growth and melanogenesis in B16-F10 cells by inducing senescence. Phytomedicine 2018, 46, 1-10. [CrossRef]

8. Peng, X.; He, Y.; Gao, Y.; Duan, F.; Chen, J.; Ruan, H. Cytochalasins from an endophytic fungus Phoma multirostrata XJ-2-1 with cell cycle arrest and TRAIL-resistance-overcoming activities. Bioorg. Chem. 2020, 104, 104317. [CrossRef] [PubMed]

9. Reynertson, K.A.; Charlson, M.E.; Gudas, L.J. Induction of murine embryonic stem cell differentiation by medicinal plant extracts. Exp. Cell Res. 2011, 317, 82-93. [CrossRef]

10. Bertheloot, D.; Latz, E.; Franklin, B.S. Necroptosis, pyroptosis and apoptosis: An intricate game of cell death. Cell. Mol. Immunol. 2021, 18, 1106-1121. [CrossRef] [PubMed]

11. Simon, H.U.; Haj-Yehia, A.; Levi-Schaffer, F. Role of reactive oxygen species (ROS) in apoptosis induction. Apoptosis 2000, 5, 415-418. [CrossRef] [PubMed]

12. Hsu, S.-K.; Chang, W.-T.; Lin, I.-L.; Chen, Y.-F.; Padalwar, N.B.; Cheng, K.-C.; Teng, Y.-N.; Wang, C.-H.; Chiu, C.-C. cancers The Role of Necroptosis in ROS-Mediated Cancer Therapies and Its Promising Applications. Cancers 2020, 12, 2185. [CrossRef]

13. Shen, Y.; Liu, W.-W.; Zhang, X.; Shi, J.-G.; Jiang, S.; Zheng, L.; Qin, Y.; Liu, B.; Shi, J.-H. TRAF3 promotes ROS production and pyroptosis by targeting ULK1 ubiquitination in macrophages. FASEB J. 2020, 34, 7144-7159. [CrossRef]

14. Somaida, A.; Tariq, I.; Ambreen, G.; Abdelsalam, A.M.; Ayoub, A.M.; Wojcik, M.; Dzoyem, J.P.; Bakowsky, U. Potent cytotoxicity of four cameroonian plant extracts on different cancer cell lines. Pharmaceuticals 2020, 13, 357. [CrossRef]

15. Khan, T.; Ali, M.; Khan, A.; Nisar, P.; Jan, S.A.; Afridi, S.; Shinwari, Z.K. Anticancer plants: A review of the active phytochemicals, applications in animal models, and regulatory aspects. Biomolecules 2020, 10, 47. [CrossRef]

16. Majid, M.Z.; Zaini, Z.M.; Razak, F.A. Apoptosis-Inducing Effect of Three Medicinal Plants on Oral Cancer Cells KB and ORL-48. Sci. World J. 2014, 125353. [CrossRef]

17. Jiang, M.; Qi, L.; Li, L.; Li, Y. The caspase-3/GSDME signal pathway as a switch between apoptosis and pyroptosis in cancer. Cell Death Discov. 2020, 6, 112. [CrossRef]

18. Wang, L.; Qin, X.; Liang, J.; Ge, P. Induction of Pyroptosis: A Promising Strategy for Cancer Treatment. Front. Oncol. 2021, 11, 635774. [CrossRef] 
19. Fang, Y.; Tian, S.; Pan, Y.; Li, W.; Wang, Q.; Tang, Y.; Yu, T.; Wu, X.; Shi, Y.; Ma, P.; et al. Pyroptosis: A new frontier in cancer. Biomed. Pharmacother. 2020, 121, 109595. [CrossRef] [PubMed]

20. Sarcognato, S.; Jong, I.E.M.; Fabris, L.; Cadamuro, M.; Guido, M. Necroptosis in Cholangiocarcinoma. Cells 2020, 9, 982. [CrossRef] [PubMed]

21. Gong, Y.; Fan, Z.; Luo, G.; Yang, C.; Huang, Q.; Fan, K.; Cheng, H.; Jin, K.; Ni, Q.; Yu, X.; et al. The role of necroptosis in cancer biology and therapy. Mol. Cancer 2019, 18, 100. [CrossRef]

22. Lou, J.; Zhou, Y.; Feng, Z.; Ma, M.; Yao, Y.; Wang, Y.; Deng, Y.; Wu, Y. Caspase-Independent Regulated Necrosis Pathways as Potential Targets in Cancer Management. Front. Oncol. 2021, 10, 616952. [CrossRef]

23. Nanni, V.; Di Marco, G.; Sacchetti, G.; Canini, A.; Gismondi, A. Oregano phytocomplex induces programmed cell death in melanoma lines via mitochondria and DNA damage. Foods 2020, 9, 1486. [CrossRef]

24. Balhamar, S.O.M.S.; Panicker, N.G.; Akhlaq, S.; Qureshi, M.M.; Ahmad, W.; Rehman, N.U.; Ali, L.; Al-Harrasi, A.; Hussain, J.; Mustafa, F. Differential cytotoxic potential of acridocarpus orientalis leaf and stem extracts with the ability to induce multiple cell death pathways. Molecules 2019, 24, 3976. [CrossRef] [PubMed]

25. Mohamed, L.; Chakraborty, S.; ArulJothi, K.N.; Mabasa, L.; Sayah, K.; Costa-Lotufo, L.V.; Jardine, A.; Prince, S. Galenia africana plant extract exhibits cytotoxicity in breast cancer cells by inducing multiple programmed cell death pathways. Saudi Pharm. J. 2020, 28, 1155-1165. [CrossRef] [PubMed]

26. Pujari, I.; Thomas, A.; Thomas, J.; Jhawar, N.; Guruprasad, K.P.; Rai, P.S.; Satyamoorthy, K.; Babu, V.S. Cytotoxicity and radiosensitizing potency of Moscatilin in cancer cells at low radiation doses of X-ray and UV-C. 3 Biotech 2021, 11, 281. [CrossRef] [PubMed]

27. Adham, A.N.; Hegazy, M.E.F.; Naqishbandi, A.M.; Efferth, T. Induction of apoptosis, autophagy and ferroptosis by Thymus vulgaris and Arctium lappa extract in leukemia and multiple myeloma cell lines. Molecules 2020, 25, 5016. [CrossRef]

28. Lee, S.; Lee, J.S. Cellular senescence: A promising strategy for cancer therapy. BMB Rep. 2019, 52, 35-41. [CrossRef] [PubMed]

29. Demirci, D.; Dayanc, B.; Mazi, F.A.; Senturk, S. The Jekyll and Hyde of Cellular Senescence in Cancer. Cells 2021, 10, 208. [CrossRef] [PubMed]

30. Mikuła-Pietrasik, J.; Niklas, A.; Uruski, P.; Tykarski, A.; Książek, K. Mechanisms and significance of therapy-induced and spontaneous senescence of cancer cells. Cell. Mol. Life Sci. 2020, 77, 213-229. [CrossRef]

31. Milczarek, M. The premature senescence in breast cancer treatment strategy. Cancers 2020, 12, 1815. [CrossRef]

32. Li, L.H.; Wu, P.; Lee, J.Y.; Li, P.R.; Hsieh, W.Y.; Ho, C.C.; Ho, C.L.; Chen, W.J.; Wang, C.C.; Yen, M.Y.; et al. Hinokitiol induces DNA damage and autophagy followed by cell cycle arrest and senescence in gefitinib-resistant lung adenocarcinoma cells. PLoS ONE 2014, 9, e104203.

33. Zheng, T.; Que, Z.; Jiao, L.; Kang, Y.; Gong, Y.; Yao, J.; Ma, C.; Bi, L.; Dong, Q.; Zhao, X.; et al. Herbal formula YYJD inhibits tumor growth by inducing cell cycle arrest and senescence in lung cancer. Sci. Rep. 2017, 7, 4984. [CrossRef] [PubMed]

34. Blagosklonny, M.V. Cell cycle arrest is not senescence. Aging 2011, 3, 94-101. [CrossRef] [PubMed]

35. Nguyen, L.T.; Lee, Y.H.; Sharma, A.R.; Park, J.B.; Jagga, S.; Sharma, G.; Lee, S.S.; Nam, J.S. Quercetin induces apoptosis and cell cycle arrest in triple-negative breast cancer cells through modulation of Foxo3a activity. Korean J. Physiol. Pharmacol. 2017, 21, 205-213. [CrossRef]

36. Dalimunthe, A.; Hasibuan, P.A.Z.; Satria, D. Cell cycle arrest activity of Litsea cubeba lour: Heartwood and fruit extracts against T47D breast cancer cells. Asian J. Pharm. Clin. Res. 2017, 10, 404-406. [CrossRef]

37. De Souza Grinevicius, V.M.A.; Kviecinski, M.R.; Santos Mota, N.S.R.; Ourique, F.; Porfirio Will Castro, L.S.E.; Andreguetti, R.R.; Gomes Correia, J.F.; Filho, D.W.; Pich, C.T.; Pedrosa, R.C. Piper nigrum ethanolic extract rich in piperamides causes ROS overproduction, oxidative damage in DNA leading to cell cycle arrest and apoptosis in cancer cells. J. Ethnopharmacol. 2016, 189, 139-147. [CrossRef]

38. Chen, V.; Staub, R.E.; Fong, S.; Tagliaferri, M.; Cohen, I.; Shtivelman, E. Bezielle selectively targets mitochondria of cancer cells to inhibit glycolysis and OXPHOS. PLOS ONE 2012, 7, e0030300. [CrossRef]

39. Perez, A.T.; Arun, B.; Tripathy, D.; Tagliaferri, M.A.; Shaw, H.S.; Kimmick, G.G.; Cohen, I.; Shtivelman, E.; Caygill, K.A.; Grady, D.; et al. A phase 1B dose escalation trial of Scutellaria barbata (BZL101) for patients with metastatic breast cancer. Breast Cancer Res. Treat. 2010, 120, 111-118. [CrossRef]

40. Rugo, H.; Shtivelman, E.; Perez, A.; Vogel, C.; Franco, S.; Tan Chiu, E.; Melisko, M.; Tagliaferri, M.; Cohen, I.; Shoemaker, M.; et al. Phase I trial and antitumor effects of BZL101 for patients with advanced breast cancer. Breast Cancer Res. Treat. 2007, 105, 17-28. [CrossRef]

41. Zhang, G.; Wang, Y.; Zhang, Y.; Wan, X.; Li, J.; Liu, K.; Wang, F.; Liu, Q.; Yang, C.; Yu, P.; et al. Anti-Cancer Activities of Tea Epigallocatechin-3-Gallate in Breast Cancer Patients under Radiotherapy. Curr. Mol. Med. 2012, 12, 163-176. [CrossRef] [PubMed]

42. Kapinova, A.; Stefanicka, P.; Kubatka, P.; Zubor, P.; Uramova, S.; Kello, M.; Mojzis, J.; Blahutova, D.; Qaradakhi, T.; Zulli, A.; et al Are plant-based functional foods better choice against cancer than single phytochemicals? A critical review of current breast cancer research. Biomed. Pharmacother. 2017, 96, 1465-1477. [CrossRef]

43. Jasek, K.; Kubatka, P.; Samec, M.; Liskova, A.; Smejkal, K.; Vybohova, D.; Bugos, O.; Biskupska-Bodova, K.; Bielik, T.; Zubor, P.; et al. DNA methylation status in cancer disease: Modulations by plant-derived natural compounds and dietary interventions. Biomolecules 2019, 9, 289. [CrossRef] [PubMed] 
44. Elix, J.A.; Stocker-Wörgötter, E. Biochemistry and Secondary Metabolites. In Lichen Biology, 2nd ed.; Nash, T.H., Ed.; Cambridge University Press: New York, NY, USA, 2008; pp. 104-133.

45. Solárová, Z.; Liskova, A.; Samec, M.; Kubatka, P.; Büsselberg, D.; Solár, P. Anticancer potential of lichens' secondary metabolites. Biomolecules 2020, 10, 87. [CrossRef]

46. Vartia, K.O. Antibiotics in Lichens. In The Lichens; Ahmadjian, V., Hale, M.E., Eds.; Academic Press: New York, NY, USA, 1973; pp. 547-558.

47. Fahselt, D. Secondary biochemistry of lichens. Symbiosis 1994, 1, 117-165.

48. Shrestha, G.; Clair, L.L. Lichens: A promising source of antibiotic and anticancer drugs. Phytochem. Rev. 2013, 12, 229-244. [CrossRef]

49. Cardile, V.; Graziano, A.C.E.; Avola, R.; Piovano, M.; Russo, A. Potential anticancer activity of lichen secondary metabolite physodic acid. Chem. Biol. Interact. 2017, 263, 36-45. [CrossRef] [PubMed]

50. Chang, T.C.; Chen, Y.C.; Huang, Y.C.; Lin, W.C.; Lu, C.H. Systemic oxidative stress and cognitive function in Parkinson's disease with different PWMH or DWMH lesions. BMC Neurol. 2021, 21, 16. [CrossRef]

51. Yang, Y.; Nguyen, T.T.; Jeong, M.H.; Crişan, F.; Yu, Y.H.; Ha, H.H.; Choi, K.H.; Jeong, H.G.; Jeong, T.C.; Lee, K.Y.; et al. Inhibitory activity of (+)-usnic acid against non-small cell lung cancer cell motility. PLoS ONE 2016, 11, e0146575. [CrossRef]

52. Zhou, R.; Yang, Y.; Park, S.Y.; Nguyen, T.T.; Seo, Y.W.; Lee, K.H.; Lee, J.H.; Kim, K.K.; Hur, J.S.; Kim, H. The lichen secondary metabolite atranorin suppresses lung cancer cell motility and tumorigenesis. Sci. Rep. 2017, 7, 8136. [CrossRef]

53. Nguyen, T.T.H.; Dinh, M.H.; Chi, H.T.; Wang, S.L.; Nguyen, Q.V.; Tran, T.D.; Nguyen, A.D. Antioxidant and cytotoxic activity of lichens collected from Bidoup Nui Ba National Park, Vietnam. Res. Chem. Intermed. 2019, 45, 33-49. [CrossRef]

54. Taş, İ.; Han, J.; Park, S.Y.; Yang, Y.; Zhou, R.; Gamage, C.D.B.; Van Nguyen, T.; Lee, J.Y.; Choi, Y.J.; Yu, Y.H.; et al. Physciosporin suppresses the proliferation, motility and tumourigenesis of colorectal cancer cells. Phytomedicine 2019, 56, 10-20. [CrossRef]

55. Bjerke, J.W.; Elvebakk, A.; Domínguez, E.; Dahlback, A. Seasonal trends in usnic acid concentrations of Arctic, alpine and Patagonian populations of the lichen Flavocetraria nivalis. Phytochemistry 2005, 66, 337-344. [CrossRef]

56. Ingolfsdóttir, K. Usnic acid. Phytochemistry 2002, 61, 729-736. [CrossRef]

57. Araújo, A.A.S.; De Melo, M.G.D.; Rabelo, T.K.; Nunes, P.S.; Santos, S.L.; Serafini, M.R.; Santos, M.R.V.; Quintans, L.J.; Gelain, D.P. Review of the biological properties and toxicity of usnic acid. Nat. Prod. Res. 2015, 29, 2167-2180. [CrossRef]

58. Luzina, O.A.; Salakhutdinov, N.F. Biological activity of usnic acid and its derivatives: Part 2. effects on higher organisms. Molecular and physicochemical aspects. Russ. J. Bioorg. Chem. 2016, 42, 249-268. [CrossRef]

59. Galanty, A.; Paśko, P.; Podolak, I. Enantioselective activity of usnic acid: A comprehensive review and future perspectives. Phytochem. Rev. 2019, 18, 527-548. [CrossRef]

60. Prateeksha; Paliya, B.S.; Bajpai, R.; Jadaun, V.; Kumar, J.; Kumar, S.; Upreti, D.K.; Singh, B.N.R.; Nayaka, S.; Joshi, Y.; et al. The genus Usnea: A potent phytomedicine with multifarious ethnobotany, phytochemistry and pharmacology. RSC Adv. 2016, 26, 21672-21696.

61. Popovici, V.; Bucur, L.; Popescu, A.; Schröder, V.; Costache, T.; Rambu, D.; Cucolea, I.E.; Gîrd, C.E.; Caraiane, A.; Gherghel, D.; et al. Antioxidant and cytotoxic activities of usnea barbata (L.) f.h. wigg. dry extracts in different solvents. Plants 2021, 10, 99. [CrossRef] [PubMed]

62. Sigma Aldrich IR Spectrum Table \& Chart I Sigma-Aldrich. IR Spectr. Table Chart 2018, 10, 909.

63. Massarczyk, M.; Rudack, T.; Schlitter, J.; Kuhne, J.; Kötting, C.; Gerwert, K. Local Mode Analysis: Decoding IR Spectra by Visualizing Molecular Details. J. Phys. Chem. B 2017, 121, 3483-3492. [CrossRef]

64. Winter, A. How to Identify Carbonyls, Alkenes, Alkynes, and Aromatics in the IR Spectrum. Dummies 2020. Available online: https:/ / www.dummies.com/education/science/chemistry/how-to-identify-carbonyls-alkenes-alkynes-and-aromaticsin-the-ir-spectrum/ (accessed on 25 June 2021).

65. Mosmann, T. Rapid colorimetric assay for cellular growth and cytotoxicity assays. J. Immunol. Methods 1983, 65, 55-63. [CrossRef]

66. Laville, N.; Aït-Ässa, S.; Gomez, E.; Casellas, C.; Porcher, J.M. Effects of human pharmaceuticals on cytotoxicity, EROD activity and ROS production in fish hepatocytes. Toxicology 2004, 196, 41-55. [CrossRef] [PubMed]

67. Denizot, F.; Lang, R. Rapid colorimetric assay for cell growth and survival. Modifications to the tetrazolium dye procedure giving improved sensitivity and reliability. J. Immunol. Methods 1986, 89, 271-277. [CrossRef]

68. Van Meerloo, J.; Kaspers, G.J.L.; Cloos, J. Cell sensitivity assays: The MTT assay. Methods Mol. Biol. 2011, 731, $237-245$.

69. Stockert, J.C.; Blázquez-Castro, A.; Cañete, M.; Horobin, R.W.; Villanueva, Á. MTT assay for cell viability: Intracellular localization of the formazan product is in lipid droplets. Acta Histochem. 2012, 114, 785-796. [CrossRef] [PubMed]

70. Liang, C.C.; Park, A.Y.; Guan, J.L. In vitro scratch assay: A convenient and inexpensive method for analysis of cell migration in vitro. Nat. Protoc. 2007, 2, 329-333. [CrossRef]

71. Pinto, B.I.; Cruz, N.D.; Lujan, O.R.; Propper, C.R.; Kellar, R.S. In Vitro Scratch Assay to Demonstrate Effects of Arsenic on Skin Cell Migration. J. Vis. Exp. 2019, 144, 329-333. [CrossRef]

72. Franken, N.A.P.; Rodermond, H.M.; Stap, J.; Haveman, J.; van Bree, C. Clonogenic assay of cells in vitro. Nat. Protoc. 2006, 1, 2315-2319. [CrossRef]

73. Rafehi, H.; Orlowski, C.; Georgiadis, G.T.; Ververis, K.; El-Osta, A.; Karagiannis, T.C. Clonogenic assay: Adherent cells. J. Vis. Exp. 2011, 10, 2573. [CrossRef]

74. Collins, T.J. ImageJ for microscopy. Biotechniques 2007, 43, S25-S30. [CrossRef] 
75. Weydert, C.J.; Cullen, J.J. Measurement of superoxide dismutase, catalase and glutathione peroxidase in cultured cells and tissue. Nat. Protoc. 2010, 5, 51-66. [CrossRef] [PubMed]

76. Ohkawa, H.; Ohishi, N.; Yagi, K. Assay for lipid peroxides in animal tissues by thiobarbituric acid reaction. Anal. Biochem. 1979, 95, 351-358. [CrossRef]

77. Winterbourn, C.C.; Hawkins, R.E.; Brian, M.; Carrell, R.W. The estimation of red cell superoxide dismutase activity. J. Lab. Clin. Med. 1975, 85, 337-341. [PubMed]

78. Sinha, A.K. Colorimetric assay of catalase. Anal. Biochem. 1972, 7, 389-394. [CrossRef]

79. Fukuzawa, K.; Tokumura, A. Glutathione peroxidase activity in tissues of vitamin e-deficient mice. J. Nutr. Sci. Vitaminol. 1976, 22, 405-407. [CrossRef] [PubMed]

80. Artenie, V.; Ungureanu, E. Negură Anca Mihaela, Metode de investigare a metabolismului glucidic şi lipidic. Ed. Pim Iaşi 2008, 97-102, 108-110.

81. Bradford, M.M. A rapid and sensitive method for the quantitation of microgram quantities of protein utilizing the principle of protein-dye binding. Anal. Biochem. 1976, 72, 248-254. [CrossRef]

82. Fletcher, O. Maths from Scratch for Biologists. Trans. R. Soc. Trop. Med. Hyg. 2004, 98, 390. [CrossRef]

83. Skehan, P.; Storeng, R.; Scudiero, D.; Monks, A.; Mcmahon, J.; Vistica, D.; Warren, J.T.; Bokesch, H.; Kenney, S.; Boyd, M.R. New colorimetric cytotoxicity assay for anticancer-drug screening. J. Natl. Cancer Inst. 1990, 82, 1107-1112. [CrossRef] [PubMed]

84. Carreño, E.A.; Alberto, A.V.P.; de Souza, C.A.M.; de Mello, H.L.; Henriques-Pons, A.; Alves, L.A. Considerations and technical pitfalls in the employment of the MTT assay to evaluate photosensitizers for photodynamic therapy. Appl. Sci. 2021, 11, 2603. [CrossRef]

85. Salgado, F.; Albornoz, L.; Cortéz, C.; Stashenko, E.; Urrea-Vallejo, K.; Nagles, E.; Galicia-Virviescas, C.; Cornejo, A.; Ardiles, A.; Simirgiotis, M.; et al. Secondary metabolite profiling of species of the genus usnea by UHPLC-ESI-OT-MS-MS. Molecules 2018, 23, 54. [CrossRef]

86. Reddy, D.S.; Siva, B.; Kumar, K.; Phani Babu, V.S.; Sravanthi, V.; Boustie, J.; Lakshma Nayak, V.; Tiwari, A.K.; Rao, C.H.V.; Sridhar, B.; et al. Comprehensive Analysis of Secondary Metabolites in Usnea longissima (Lichenized Ascomycetes, Parmeliaceae) Using UPLC-ESI-QTOF-MS/MS and Pro-Apoptotic Activity of Barbatic Acid. Molecules 2019, 24, 2270. [CrossRef] [PubMed]

87. Kondratiuk, A.S.; Savchuk, O.M.; Hur, J.S. Optimization of protein extraction for lichen thalli. Mycobiology 2015, 43, 157-162. [CrossRef]

88. Shukla, V.; Joshi, G.P.; Rawat, M.S.M. Lichens as a potential natural source of bioactive compounds: A review. Phytochem. Rev. 2010, 9, 303-314. [CrossRef]

89. Bézivin, C.; Tomasi, S.; Lohezic-Le Devehat, F.; Boustie, J. Cytotoxic activity of some lichen extracts on murine and human cancer cell lines. Phytomedicine 2003, 10, 499-503. [CrossRef]

90. Kosanić, M.; Ranković, B.; Stanojković, T.; Rančić, A.; Manojlović, N. Cladonia lichens and their major metabolites as possible natural antioxidant, antimicrobial and anticancer agents. LWT Food Sci. Technol. 2014, 59, 518-525. [CrossRef]

91. Emsen, B.; Ozdemir, O.; Engin, T.; Togar, B.; Cavusoglu, S.; Turkez, H. Inhibition of growth of U87MG human glioblastoma cells by Usnea longissima ach. Anais Acad. Bras. Cienc. 2019, 91, 1-14. [CrossRef] [PubMed]

92. Tang, J.Y.; Wu, K.H.; Wang, Y.Y.; Farooqi, A.A.; Huang, H.W.; Yuan, S.S.F.; Jian, R.I.; Tsao, L.Y.; Chen, P.A.; Chang, F.R.; et al. Methanol extract of usnea barbata induces cell killing, apoptosis, and dna damage against oral cancer cells through oxidative stress. Antioxidants 2020, 9, 694. [CrossRef] [PubMed]

93. Aoussar, N.; Laasri, F.E.; Bourhia, M.; Manoljovic, N.; Mhand, R.A.; Rhallabi, N.; Ullah, R.; Shahat, A.A.; Noman, O.M.; Nasr, F.A.; et al. Phytochemical analysis, cytotoxic, antioxidant, and antibacterial activities of lichens. Evid. Based Complement. Altern. Med. 2020, 8104538. [CrossRef]

94. Ari, F.; Aztopal, N.; Oran, S.; Bozdemir, S.; Celikler, S.; Ozturk, S.; Ulukaya, E. Parmelia sulcata Taylor and Usnea filipendula Stirt induce apoptosis-like cell death and DNA damage in cancer cells. Cell Prolif. 2014, 47, 457-464. [CrossRef] [PubMed]

95. Zugic, A.; Jeremic, I.; Isakovic, A.; Arsic, I.; Savic, S.; Tadic, V. Evaluation of anticancer and antioxidant activity of a commercially available CO2 supercritical extract of old man's beard (Usnea barbata). PLoS ONE 2016, 11, e0146342. [CrossRef]

96. Tram, N.T.T.; Anh, D.H.; Thuc, H.H.; Tuan, N.T. Investigation of chemical constituents and cytotoxic activity of the lichen Usnea undulata. Vietnam J. Chem. 2020, 58, 63-66. [CrossRef]

97. Ozturk, S.; Erkisa, M.; Oran, S.; Ulukaya, E.; Celikler, S.; Ari, F. Lichens exerts an anti-proliferative effect on human breast and lung cancer cells through induction of apoptosis. Drug Chem. Toxicol. 2019, 44, 259-267. [CrossRef]

98. Popovici, V.; Bucur, L.A.; Schröder, V.; Gherghel, D.; Mihai, C.T.; Caraiane, A.; Badea, F.C.; Vochița, G.; Badea, V. Evaluation of the cytotoxic activity of the Usnea barbata (L.) F. H. Wigg dry extract. Molecules 2020, 8, 1865. [CrossRef]

99. Zambare, V.P.; Christopher, L.P. Biopharmaceutical potential of lichens. Pharm. Biol. 2012, 50, 778-798. [CrossRef]

100. Sepahvand, A.; Studzińsk-Sroka, E.; Ramak, P.; Karimian, V. Usnea sp.: Antimicrobial potential, bioactive compounds, ethnopharmacological uses and other pharmacological properties; a review article. J. Ethnopharmacol. 2021, 268, 113656. [CrossRef]

101. Zhang, Z.; Zheng, Y.; Li, Y.; Bai, H.; Ma, T.; Song, X.; Zhao, J.; Gao, L. The effects of sodium usnic acid by topical application on skin wound healing in rats. Biomed Pharmacother. 2018, 97, 587-593. [CrossRef]

102. Burlando, B.; Ranzato, E.; Volante, A.; Appendino, G.; Pollastro, F.; Verotta, L. Antiproliferative effects on tumour cells and promotion of keratinocyte wound healing by different lichen compounds. Planta Med. 2009, 75, 607-613. [CrossRef] 
103. Bruno, M.; Trucchi, B.; Burlando, B.; Ranzato, E.; Martinotti, S.; Akkol, E.K.; Süntar, I.; Keleş, H.; Verotta, L. (+)-Usnic acid enamines with remarkable cicatrizing properties. Bioorg. Med. Chem. 2013, 21, 1834-1843. [CrossRef]

104. Brzozowska, B.; Gałecki, M.; Tartas, A.; Ginter, J.; Kaźmierczak, U.; Lundholm, L. Freeware tool for analysing numbers and sizes of cell colonies. Radiat. Environ. Biophys. 2019, 58, 109-1117. [CrossRef] [PubMed]

105. Solár, P.; Hrčková, G.; Koptašíková, L.; Velebný, S.; Solárová, Z.; Bačkor, M. Murine breast carcinoma $4 \mathrm{T1}$ cells are more sensitive to atranorin than normal epithelial NMuMG cells in vitro: Anticancer and hepatoprotective effects of atranorin in vivo. Chem. Biol. Interact. 2016, 250, 27-37. [CrossRef] [PubMed]

106. Guzow-Krzemińska, B.; Guzow, K.; Herman-Antosiewicz, A. Usnic Acid Derivatives as Cytotoxic Agents Against Cancer Cells and the Mechanisms of Their Activity. Curr. Pharmacol. Rep. 2019, 5, 429-439. [CrossRef]

107. Pyrczak-Felczykowska, A.; Narlawar, R.; Pawlik, A.; Guzow-Krzemińska, B.; Artymiuk, D.; Hać, A.; Ryś, K.; Rendina, L.M.; Reekie, T.A.; Herman-Antosiewicz, A.; et al. Synthesis of Usnic Acid Derivatives and Evaluation of Their Antiproliferative Activity against Cancer Cells. J. Nat. Prod. 2019, 82, 1768-1778. [CrossRef]

108. Glorieux, C.; Sandoval, J.M.; Fattaccioli, A.; Dejeans, N.; Garbe, J.C.; Dieu, M.; Verrax, J.; Renard, P.; Huang, P.; Calderon, P.B. Chromatin remodeling regulates catalase expression during cancer cells adaptation to chronic oxidative stress. Free Radic. Biol. Med. 2016, 99, 436-450. [CrossRef]

109. Studzińska-Sroka, E.; Piotrowska, H.; Kucińska, M.; Murias, M.; Bylka, W. Cytotoxic activity of physodic acid and acetone extract from Hypogymnia physodes against breast cancer cell lines. Pharm. Biol. 2016, 54, 2480-2485. [CrossRef]

110. Paluszczak, J.; Kleszcz, R.; Studzińska-Sroka, E.; Krajka-Kuźniak, V. Lichen-derived caperatic acid and physodic acid inhibit Wnt signaling in colorectal cancer cells. Mol. Cell. Biochem. 2018, 441, 109-124. [CrossRef]

111. Odabasoglu, F.; Cakir, A.; Suleyman, H.; Aslan, A.; Bayir, Y.; Halici, M.; Kazaz, C. Gastroprotective and antioxidant effects of usnic acid on indomethacin-induced gastric ulcer in rats. J. Ethnopharmacol. 2006, 103, 59-65. [CrossRef]

112. De Paz, G.; Raggio, J.; Gómez-Serranillos, M.P.; Palomino, O.M.; González-Burgos, E.; Carretero, M.E.; Crespo, A. HPLC isolation of antioxidant constituents from Xanthoparmelia spp. J. Pharm. Biomed. Anal. 2010, 53, 165-171. [CrossRef]

113. Su, Z.Q.; Mo, Z.Z.; Liao, J.B.; Feng, X.X.; Liang, Y.Z.; Zhang, X.; Liu, Y.H.; Chen, X.Y.; Chen, Z.W.; Su, Z.R.; et al. Usnic acid protects LPS-induced acute lung injury in mice through attenuating inflammatory responses and oxidative stress. Int. Immunopharmacol. 2014, 22, 371-378. [CrossRef] [PubMed] 